\title{
COVID-19 AND SITES OF CONFINEMENT: PUBLIC HEALTH, DISPOSABLE LIVES AND LEGAL ACCOUNTABILITY IN IMMIGRATION DETENTION AND AGED CARE
}

\author{
SARA DEHM, ${ }^{*}$ CLAIRE LOUGHNAN ${ }^{* *}$ AND LINDA STEELE ${ }^{* * *}$
}

The global COVID-19 pandemic starkly revealed the underlying structural harms and produced vulnerabilities for people living in closed congregate settings like immigration detention centres ('IDCs') and residential aged care facilities ('RACFs'). This article compares the Australian legal regimes that regulate IDCs and RACFs, conceptualising both as authorising and enabling sites of control, confinement and social isolation. We argue that specific COVID-19 measures have intensified a logic of social exclusion and disposability towards people in IDCs and RACFs. Through comparing recent COVID-19 litigation, the article explores the possibilities and limitations of engaging legal strategies to achieve social reform and legal accountability within both sites of confinement. Ultimately, we suggest that such COVID-19 litigation has the greatest possibility of advancing social justice when it is embedded in a broader politics of de-incarceration and abolition oriented towards political inclusion, public health and building more equitable and just communities.

\section{INTRODUCTION}

In March 2020, the Communicable Diseases Network Australia ('CDNA') ${ }^{1}$ adopted two distinct sets of COVID-19 guidelines in response to the global pandemic: one set applicable to residential aged care facilities ('RACFs'); and the other applicable to correctional and detention facilities, including custodial prisons and immigration detention centres ('IDCs'). ${ }^{2}$ While the adoption of two sets of

\footnotetext{
* $\quad$ Senior Lecturer, Faculty of Law, University of Technology Sydney.

** Lecturer, School of Social and Political Sciences, University of Melbourne.

*** Senior Lecturer, Faculty of Law, University of Technology Sydney; Honorary Fellow, Faculty of Business and Law, University of Wollongong. Thank you to John Karantzis and Stacey Patsias for their assistance accessing court documents related to Part IV(C) of this article.

1 The CDNA is a joint initiative of the National Health and Medical Research Council, and the Australian Health Ministers' Advisory Council.

2 See Communicable Diseases Network Australia, 'CDNA National Guidelines for the Prevention, Control and Public Health Management of COVID-19 Outbreaks in Residential Care Facilities in Australia' (Guidelines, 13 March 2020) <https://www.health.gov.au/sites/default/files/documents/2020/07/cdna-
} 
guidelines implies a formal separation between different regulatory regimes, in substance, the guidelines bear striking similarities. Both promote an outbreak prevention, containment and management model, prioritising practices of detection, isolation and monitoring as the primary means for limiting COVID-19 infection exposure and transmission within closed congregate settings. This model reflects the general regulatory response to COVID-19 across sites of confinement; one that largely exacerbates experiences of confinement without necessarily offering adequate protections to the people incarcerated in IDCs nor people living in RACFs.

This article analyses Australian COVID-19 measures and legal accountability litigation across IDCs and RACFs as two key sites of confinement. ${ }^{3}$ From the start of the pandemic, experts emphasised the higher degree of vulnerability amongst older people and others with pre-existing medical conditions, including people incarcerated in IDCs. ${ }^{4}$ Additionally, and of significance to our analysis, the preventive, protective measures recommended by governments and medical experts for the general public are precisely those measures which are difficult to guarantee in confined, congregate settings like RACFs and IDCs. More disturbingly, the refusal to consider forms of accommodation or alternative care for those in RACFs and IDCs has enhanced the risk and likelihood of exposures, rather than minimised them. Accordingly, the COVID-19 global pandemic has amplified the pre-existing structural harms of these sites, and certain COVID-19

national-guidelines-for-the-prevention-control-and-public-health-management-of-covid-19-outbreaks-inresidential-care-facilities-in-australia.pdf $>$ ('COVID-19 Guidelines for RACFs'); Communicable Diseases Network Australia, 'CDNA National Guidelines for the Prevention, Control and Public Health Management of COVID-19 Outbreaks in Correctional and Detention Facilities in Australia' (Guidelines, 31 March 2020) <https://www.health.gov.au/sites/default/files/documents/2020/06/cdna-guidelines-forthe-prevention-control-and-public-health-management-of-covid-19-outbreaks-in-correctional-anddetention-facilities-in-australia_1.pdf $>$ ('COVID-19 Guidelines for IDCs'). The CDNA is a subcommittee of the Australian Health Protection Principal Committee ('AHPPC'), whose terms of reference are to 'provide national public health coordination and leadership and to support best practice for the prevention and control of communicable diseases': 'About Communicable Diseases Network Australia', Department of Health (Web Page, 25 March 2015)

$<$ https://www1.health.gov.au/internet/main/publishing.nsf/content/cda-cdna-cdna.htm\#refs $>$. For the purposes of this article, the term 'IDCs' includes any Alternative Places of Detention ('APODs') that also function as closed environments, such as the Mantra Bell City hotel in Melbourne and Kangaroo Point hotel in Brisbane.

3 See Scott Burris et al (eds), 'Assessing Legal Responses to COVID-19' (Research Paper, Public Health Law Watch, August 2020) for an assessment of legal responses to the adverse impact of the pandemic on particular communities and groups.

4 World Health Organization, Coronavirus Disease 2019 (COVID-19): Situation Report (Report No 51, 11 March 2020); 'Australian Health Protection Principal Committee (AHPPC) Advice to National Cabinet on 30 March 2020', Department of Health (Web Page, 31 March 2020)

$<$ https:/www.health.gov.au/news/australian-health-protection-principal-committee-ahppc-advice-tonational-cabinet-on-30-march-2020>; 'Urgent Action Needed to Prevent COVID-19 "Rampaging through Places of Detention”: Bachelet', Office of the High Commissioner for Human Rights (Web Page, 25 March 2020)

$<$ https://www.ohchr.org/EN/NewsEvents/Pages/DisplayNews.aspx?NewsID=25745\&LangID=E \&fbclid=IwAR1MrR1J3J3LdKub1w3GUx2WXB4AIvpXZHoWbjCRRpY70EB_E_X4vZMgcvA>. 
response measures have intensified the individual vulnerabilities of those confined there - vulnerabilities which are in part produced by the conditions of these sites. ${ }^{5}$

It might seem counterintuitive to bring together an analysis of IDCs with RACFs. While they appear to be - and in many ways are - quite disparate legal regimes and populations, both sites are marked by jurisdictional, regulatory and conceptual similarities. These connections help us to think through possibilities and limits of legal advocacy strategies to disrupt structural harms reflected by the pandemic and beyond, especially given state resistance to categorising RACFs and IDCs as sites of control, confinement and structural violence. Moreover, we argue that COVID-19 responses reveal an underlying failure to properly acknowledge and care for the lives of people in RACFs and IDCs as lives worth living or as lives worthy of protection. ${ }^{6}$ In these sites, confinement and loss of personal autonomy are experienced and rationalised in different ways that exceed the conventional focus on prisons as the hallmark of state-sanctioned carcerality and loss of individual freedom. As such, focusing on legal advocacy connected to these sites (rather than prisons) might have broader application to a range of other regimes of state control, such as quarantine, disability and child welfare, and provide further impetus for dialogues and activism across sites. Despite these parallels, we identify key differences in the litigation concerning IDCs and RACFs. This suggests that, notwithstanding their convergences as sites of confinement and control, the adoption of particular litigation measures is informed by persistent differences between them, including different mechanisms of inclusion/exclusion not limited to the legal status of the two distinct populations.

This article was written six months into Australia's COVID-19 response, offering a pertinent moment to analyse the legal regimes, human effects and legal accountability strategies across two contexts of confinement. We focus on emerging strategic litigation and class actions concerning IDCs and RACFs that utilise duty of care legal arguments to compel either release from IDCs or to promote accountability and civil remedies for deaths in RACFs. ${ }^{7}$ Our analysis draws on cases currently on foot, relying upon party submissions and interlocutory orders that are not all on the public record. This allows us to make an original contribution to understandings of how law is being used at Australia's six-month mark of the COVID-19 pandemic ('the pandemic') across sites of confinement.

This article is structured in four Parts. Part II provides an overview of the legal regimes and political dynamics of confinement in IDCs and RACFs. In Part III, we argue that COVID-19 measures are underlined by a logic of disposability towards people detained in IDCs and confined in RACFs. Even if this logic is articulated differently for each group, official pandemic responses implicitly

5 For a discussion of these heightened vulnerabilities, see the edited collection by Colleen M Flood et al (eds), Vulnerable: The Law, Policy and Ethics of COVID-19 (University of Ottawa Press, 2020).

6 Claire Loughnan, 'Un-Treatment as Neglect: The Scene and the Unseen of Quiet Violence in Aged Care and Immigration Detention', Incarcerations: An International Journal of Imprisonment, Detention and Coercive Confinement (forthcoming).

7 Our analysis does not focus on other legal arguments that could be made to advance strategic human rights or promote accountability across RACFs or IDCs, such as utilising state-based human rights charters. This is because, in part, no such legal actions have been initiated to date, partly because IDCs do not fall under the definition of a state-based 'public authority'. 
construed both populations as lives not worthy of saving or protection. Despite this, emerging litigation is contesting the institutional failure to deliver adequate care and safety. In Part IV, we trace this legal action to identify key similarities and differences in advocacy approaches, with reactive class action cases characterising responses in RACFs, and proactive strategic litigation being pursued in relation to those held in IDCs. We conclude in Part V by considering the possibilities and limitations of these legal responses for challenging underlying and longstanding structural harms of confinement, and for advancing a politics of abolition that can counter the logic of disposability at work in both contexts of confinement. ${ }^{8}$ We understand an abolitionist politics to mean not merely the closure of specific sites. Instead, it is informed by a resistance to carceral power dynamics and harmful epistemologies about marginalised populations that are used to justify their confinement or incarceration. Such a politics emphasises building just and equitable communities, informed by principles of reciprocity, respect, dignity and relationality, instead of reliance on institutionalised forms of control under the guise of 'protection'. This requires a commitment to meaningful alternatives to social isolation and abuse, rather than turning to institutionalised care to 'resolve' social needs and challenges. To move towards decarceration and abolition is to embrace a vision of social justice, systemic reform, and fair allocation of resources to end systems of oppression and inequality driving incarceration. ${ }^{9}$

\section{THE LEGAL REGULATION OF IMMIGRATION DETENTION CENTRES AND AGED CARE FACILITIES IN AUSTRALIA}

While IDCs and RACFs in Australia are subject to separate legal regimes with distinct powers and purposes, they nonetheless share a number of common features. First, both sectors are subject to Commonwealth legislative regimes that set up overall federal administrative powers, regulatory functions and oversight mechanisms. As non-criminal sites of confinement and control, this sets them apart

8 For select, foundational and recent texts on abolitionist politics, see Angela Y Davis, Are Prisons Obsolete? (Seven Stories Press, 2003); Allegra M McLeod, 'Prison Abolition and Grounded Justice' (2015) 62(5) UCLA Law Review 1156; Linda Moore, Phil Scraton and Azrini Wahidin (eds), Women's Imprisonment and the Case for Abolition: Critical Reflections on Corston Ten Years On (Routledge, 2017); Eileen Baldry, Bree Carlton and Chris Cunneen, 'Abolitionism and the Paradox of Penal Reform in Australia: Indigenous Women, Colonial Patriarchy, and Co-option’ (2015) 41(3) Social Justice 168.

9 In making an argument for abolition, we are not advocating a narrow set of measures - focused only on closure of IDCs and RACFs without any provision of social support and resources or broader social transformation - which could lead to dramatic increases in homelessness, trans-institutionalisation and the experience of living in an 'open air prison'. This would merely contribute to new forms of abandonment, control and violence towards 'disposable' bodies. See Liat Ben-Moshe, 'Disepistemologies of Abolition' (2018) 26(3) Critical Criminology 341; Liat Ben-Moshe, 'Why Prisons Are Not "The New Asylums"” (2017) 19(3) Punishment \& Society 272; Maria Giannacopoulos and Claire Loughnan, "Closure” at Manus Island and Carceral Expansion in the Open Air Prison' (2020) 17(7) Globalizations 1118. For emerging abolitionist scholarship in a United States immigration prison context, see César Cuauhtémoc García Hernández, ‘Abolishing Immigration Prisons' (2017) 97(1) Boston University Law Review 245; Allison Crennen-Dunlap, 'Abolishing the ICEberg' [2018-19] 96 Denver Law Review 148. 
from custodial prisons and juvenile 'justice centres' that primarily fall under the responsibility of state or territory jurisdiction. ${ }^{10}$ Second, there are important historical parallels across how these federal legislative regimes have allowed both sectors to operate in practice. Most notably, both legal regimes allow for the privatisation of services, a characteristic which emerged during the Howard years. ${ }^{11}$ Privatisation introduced a profit-motive in both sectors that sits ambivalently alongside service models supposedly offering care, welfare and humanitarian support. Finally, both regimes at times are justified as dedicated to the safety and security of those detained or residing there; yet both are marked by a violent loss of autonomy for individuals subject to these regimes. For example, in 2001, the then Minister for Immigration and Multicultural Affairs rejected claims that immigration detention amounted to punishment, retorting that 'it is not misery for people to be in a situation of safety and security.12 Immigration detention is nonetheless experienced (intentionally) as punishment, even if its stated administrative purpose is for 'manag[ing]' unauthorised non-citizens and upholding the 'integrity' of Australia's migration system. ${ }^{13}$ In RACFs, there is an expectation that residents are there to receive support and protection in the final stages of their life. ${ }^{14}$ In both regimes, we have seen persistent patterns of abuse and neglect, including through restrictive practices against those deemed a threat to others or to themselves. Although we acknowledge that, for some people, RACFs might provide a social, supportive environment (or at least the promise of this) and are commonly seen as a beneficial alternative to social isolation and family abuse, it is clear from the Royal Commission into Aged Care Quality and Safety ${ }^{15}$ ('Royal Commission') that there is a high incidence of violence and

10 See, eg, Prisons Act 1952 (NSW); Children (Detention Centres) Act 1987 (NSW); Corrections Act 1986 (Vic); Children, Youth and Families Act 2005 (Vic).

11 This covers the period between 1996 and 2007, during the Prime Ministership of John Howard.

12 'Ruddock Rejects Criticism', $A M$ (ABC Local Radio, 16 November 2001)

$<$ http://www.abc.net.au/am/stories/s418255.htm>.

13 'Immigration Detention in Australia', Australian Border Force (Web Page, 24 January 2019) $<$ https://www.abf.gov.au/about-us/what-we-do/border-protection/immigration-detention>. On the administrative nature of immigration detention, see Lim v Minister for Immigration, Local Government and Ethnic Affairs (1992) 176 CLR 1. On experiences of Australian onshore immigration detention as prisons, see Michelle Peterie, 'Deprivation, Frustration, and Trauma: Immigration Detention Centres as Prisons' (2018) 37(3) Refugee Survey Quarterly 279, 291-3.

14 Greg McIntosh and Janet Phillips, "“Caring for the Elderly": An Overview of Aged Care Support Services in Australia', Parliament of Australia (E-Brief, 27 February 2003)

$<$ https://www.aph.gov.au/About_Parliament/Parliamentary_Departments/Parliamentary_Library/Publicat ions_Archive/archive/agedcare>.

15 'Royal Commission into Aged Care Quality and Safety: Experimental Estimates of the Prevalence of Elder Abuse in Australian Aged Care Facilities' (Research Paper No 17, December 2020) 1; Royal Commission into Aged Care Quality and Safety (Interim Report, 31 October 2019). See also Human Rights Watch, 'Fading Away': How Aged Care Facilities in Australia Chemically Restrain Older People with Dementia (Report, October 2019); Daisy Smith et al, 'The Epidemiology of Sexual Assault of Older Female Nursing Home Residents, in Victoria Australia, Between 2000 and 2015' (2019) 36 Legal Medicine 89. 
neglect in RACFs. This reveals how a system rationalised on ideas of safety and security perversely can 'deliver other [kinds of] violences'. ${ }^{16}$

Nonetheless, important legal, practical and political distinctions remain between the two legal regimes. While immigration detention is purportedly administrative in nature, in practice IDCs operate much like prisons and are experienced as punitive settings. ${ }^{17}$ In contrast, the regulation of RACFs is focused on ensuring 'service delivery' of care through funding models aimed at facilitating quality of life, access and choice for older people. In practice, these largely privately-run (whether for profit or not for profit) secure facilities are segregated from society, offering limited social integration or even lack of freedom of mobility for residents. ${ }^{18}$ Importantly, IDCs and RACFs are sites of confinement, where individuals can be subjected to detention, surveillance, segregation and social isolation. As marginalised populations, they are often kept out of view, and may not be conceptualised as part of the community at large. ${ }^{19}$ Both can be places of trauma and suffering, characterised by systemic breaches of human rights and emerging from a history in Australia of quarantining and institutionalisation of certain populations. ${ }^{20}$

\section{A Immigration Detention Centres}

Australia has had a policy of mandatorily detaining people classified as 'unlawful non-citizens' since 1992. ${ }^{21}$ Under the Migration Act 1958 (Cth) ('the Migration Act'), an 'unlawful non-citizen' is considered to be any person in Australia who is not an Australian citizen and who does not hold a valid visa. ${ }^{22}$ As a consequence, they must be kept in IDCs until they either depart (or are deported) from Australia or are granted a valid visa. ${ }^{23}$ While most 'unlawful noncitizens' can apply for bridging visas while they are in IDCs, asylum seekers who have arrived in Australia unauthorised by boat (termed 'unauthorised maritime

16 Claire Loughnan, "Not the Hilton": "Vernacular Violence" in COVID-19 Quarantine and Detention Hotels' [2020] (3) Arena 39, $45<$ https://arena.org.au/not-the-hilton-vernacular-violence-in-covid-19quarantine-and-detention-hotels/ $>$.

17 Joseph Pugliese, 'The Tutelary Architecture of Immigration Detention Prisons and the Spectacle of "Necessary Suffering"” (2008) 13(2) Architectural Theory Review 206, 208-10.

18 See, eg, Linda Steele et al, 'Human Rights and the Confinement of People Living with Dementia in Care Homes' (2020) 22(1) Health and Human Rights Journal 7; Linda Steele et al, 'Questioning Segregation of People Living with Dementia in Australia: An International Human Rights Approach to Care Homes' (2019) 8(3) Laws 18 ('Questioning Segregation of People Living with Dementia in Australia').

19 Steele et al, 'Questioning Segregation of People Living with Dementia in Australia' (n 18) 2.

20 Alison Bashford and Carolyn Strange, 'Isolation and Exclusion in the Modern World: An Introductory Essay' in Alison Bashford and Carolyn Strange (eds), Isolation: Places and Practices of Exclusion (Routledge, 2003) 3-4, 8; Alison Bashford and Carolyn Strange, 'Asylum-Seekers and National Histories of Detention' (2002) 48(4) Australian Journal of Politics and History 509, 515-17; Amy Nethery, 'Separate and Invisible: A Carceral History of Australian Islands' (2012) 6(2) Shima 85, 96.

21 Janet Phillips and Harriet Spinks, 'Immigration Detention in Australia' (Background Note, Parliamentary Library, Parliament of Australia, 20 March 2013) 1, 7.

22 Migration Act 1958 (Cth) ss 13(1), 14.

23 Ibid ss 189, 196(1). Under s 5, the term 'detain' means to 'take into immigration detention; or keep, or cause to be kept, in immigration detention; and includes taking such action and using such force as are reasonably necessary to do so'. Under s 196(1) the Act states that detention ends when the unlawful noncitizen is removed from Australia, deported, or granted a valid visa. 
arrivals' or 'designated persons' in the Act) cannot. ${ }^{24}$ Instead, they must wait until the Minister grants them a bridging visa if the Minister deems it 'in the public interest to do so'. ${ }^{25}$ This power is held by the Minister personally, meaning that it is considered a discretionary, non-compellable power under the Migration Act and not subject to judicial review. ${ }^{26}$ The Migration Act states that courts are prevented from releasing unlawful non-citizens from IDCs. ${ }^{27}$

The Migration Act's definition of 'immigration detention' is permissively broad, including holding a person in an IDC established under the Act, or in a prison, a police station, certain vessels and 'another place approved by the Minister in writing, ${ }^{28}$ The Migration Act also provides the Minister with the power to 'establish' and 'maintain' IDCs, including making regulations for their 'operation and regulation' and for the 'conduct and supervision of detainees' ${ }^{29}$ In effect, this enables the Minister and departmental officers 'to determine the places at which and the manner in which a person in immigration detention is to be detained, ${ }^{30}$ Australia's onshore immigration detention network currently consists of numerous closed, high-security facilities as well as so-called Alternative Places of Detention ('APODs') like suburban hotels, hospitals, psychiatric facilities, or foster care arrangements. ${ }^{31}$

Since November 1997, the Commonwealth government has outsourced the daily operation of IDCs to private, for-profit operators. In practice, only one main operator has been awarded the so-called 'onshore' immigration detention services

24 Ibid ss 46A, 5AA.

25 Ibid s 195A; see also s 46A(2) that enables the Minister to allow an 'unauthorised maritime arrival' to make a valid application for a visa. 'Immigration Detention in Australia', Australian Border Force (Web Page, 11 December 2020) <https://www.abf.gov.au/about-us/what-we-do/border-protection/immigrationdetention/detention-facilities $>$ : This site lists the key facilities operating on the Australian mainland and does not list the Christmas Island detention centre. A recent statement regarding proposals to move those being detained on the mainland to Christmas Island can be found here: Australian Border Force,

'Statement regarding Christmas Island' (Media Release, 4 August 2020)

$<$ https://newsroom.abf.gov.au/releases/statement-regarding-christmas-island $>$. For a history, see Anthea Vogl, 'Crimmigration and Refugees: Bridging Visas, Criminal Cancellations and "Living in the Community" as Punishment and Deterrence' in Peter Billings (ed), Crimmigration in Australia: Law, Politics, and Society (Springer, 2019) 149. For the punitive effects of bridging visas as well as a discussion of the various coping strategies of asylum seekers living in the community, see Caroline Fleay and Lisa Hartley, "'I Feel Like a Beggar”: Asylum Seekers Living in the Australian Community Without the Right to Work' (2016) 17(4) Journal of International Migration and Integration 1031.

26 Migration Act 1958 (Cth) s 46A(7); Department of Parliamentary Services (Cth), Bills Digest (Digest No 40 of 2014-15, 23 October 2014) 19. Section 46A(7) of the Act describes the discretionary and noncompellable nature of the Minister's powers.

27 Migration Act 1958 (Cth) s 196(3).

28 Ibid s 5. It also includes being restrained by certain officers of the Commonwealth including Border Force officials, Australian Federal Police members, or any other person authorised by the Minister for the purposes of the Act; and includes people covered by residence determinations under s 197AC.

29 Ibid s 273

30 MZYYR v Secretary, Department of Immigration and Citizenship (2012) 292 ALR 659, 662 [15] (Gordon J).

31 There are presently eight main operational IDCs in Australia, including the recently-recommissioned Christmas Island Immigration Detention Centre some 1,500 km away from the Australian mainland (and 2,600 km away from the nearest capital city, Perth): 'Immigration Detention in Australia', Australian Border Force (Web Page, 11 December 2020) <https:/www.abf.gov.au/about-us/what-we-do/borderprotection/immigration-detention/detention-facilities $>$. 
contract at any given time. Since 2009, this operator has been Serco Australia Pty Ltd ('Serco'), a wholly-owned subsidiary of the United Kingdom-based multinational 'outsourcing' services company, Serco Group. ${ }^{32}$ Through outsourcing the operation of Australia's immigration detention network, the Australian government has sought to devolve certain legal obligations and practical matters to Serco. ${ }^{33}$ Nonetheless, Australian courts have held that the Commonwealth retains legal responsibility in the form of a non-delegable duty of care in relation to IDCs. ${ }^{34}$ At the end of June 2020, there were 1,523 people detained in IDCs in Australia, including in APODs. ${ }^{35}$

32 See Department of Immigration and Border Protection (Cth) and Serco Australia Pty Ltd, 'Immigration Detention Facilities and Detainee Services Contract' (Contract, 10 December 2014) <https:/www.homeaffairs.gov.au/foi/files/2017/FA161000977-documents-released.pdf> ('Detention Services Contract'). This contract is highly lucrative, with the current contract (2014-21) recently officially valued at AUD609 million. Under this arrangement, Serco is free to sub-contract additional 'service providers', although certain 'major' arrangements require Departmental approval: at vol 1 pt 7 . In recent years, this has seen Serco contracting with hotel chains such as Mantra hotel located in suburban Melbourne and Kangaroo Point hotel located in inner-city Brisbane, in order for them to be designated as APODs. For a history of IDC privatisation, see Sara Dehm, 'Outsourcing, Responsibility, and Refugee Claim-Making in Australia's Offshore Detention Regime' in Siobhán McGuirk and Adrienne Pine (eds), Asylum for Sale: Profit and Protest in the Migration Industry (PM Press, 2020) 47, 49-52.

33 The 'Detention Services Contract' (n 32), for example, obliges Serco to 'maintain an environment that supports the health and safety needs for all detainees' and other specified persons at each facility, and ensure that detainees are 'are informed of, and observe' relevant Work Health and Safety rules at each facility: at vol 1 sch 2 cls 6(b), (d). The contract also anticipates the management of emergencies and places specific obligations on Serco in relation to such emergencies, including requiring Serco to 'ensure that each Facility is a safe and secure environment for people to live and work in, and comply with all applicable Laws and Australian Standards for the control and management of emergencies': at vol 1 sch 2 $\mathrm{s} 2 \mathrm{cl}$ 7(a). In addition, Serco is obliged to deliver security services at each IDC to 'scale to accommodate the unique needs, risks and challenges associated with each Detainee, and the Detainee cohort as a whole': at vol 1 sch 2 s 4 cl 1.1(b)(iv).

34 See $S v$ Secretary, Department of Immigration and Multicultural and Indigenous Affairs (2005) 143 FCR 217, 259 [205], 261-2 [213]-[217] (Finn J); SBEG v Commonwealth (2012) 208 FCR 235, 237 [7], 239 [19] (Keane CJ, Lander and Siopis JJ).

35 Department of Home Affairs, Commonwealth of Australia, Immigration Detention and Community Statistics Summary (Report, 30 June 2020). According to the Refugee Council of Australia, there were approximately 190 men detailed in the two main APODs in Australia in August 2020: namely, around 70 men detained in the Mantra Hotel in Melbourne and approximately 120 men in the Kangaroo Point Hotel in Brisbane: Email from Sahar Okhovat to Claire Loughnan and Asher Hirsch, 27 August 2020. These are refugees and asylum seekers who were previously evacuated to Australia for medical treatment from offshore detention on Papua New Guinea and Nauru, many of whom have been detained there for 12 months or more. Like a closed immigration detention centre environment, refugees and asylum seekers have no freedom of movement in APODs or in hotel detention; yet, as APODs and hotel detention sites are not purpose-built detention centres, they can be 'exceptionally restrictive environments' that lack sufficient open spaces for recreation. This means people detained in APODs and hotel detention may be effectively confined to their rooms for most of the day, with no access to cooking facilities or recreational areas. See for example, Australian Human Rights Commission, Risk Management in Immigration Detention (Report, 2019) 48-9. At the start of 2021, many of these men were abruptly released from immigration detention, although a small cohort of men still remain at the start of March 2021. See Rachel Eddie and Rachael Dexter, "We Are Out Now": More Refugees Released from Hotel Detention in Melbourne', The Age (online, 21 January 2021) <https://www.theage.com.au/national/victoria/likeflying-dozens-more-refugees-released-from-hotel-detention-in-melbourne-20210121-p56vr3.html>; Tom Stayner, “"They Are Human Beings": Released Medevac Detainees Call for "Permanent” Resettlement 
The operation of Australia's immigration detention network is subject to oversight at the Federal level by, for example, the Commonwealth Ombudsman, Comcare, the Australian Human Rights Commission, ad hoc Senate Committees, and the Australian National Audit Office. The system has long attracted vocal criticism and opposition from those detained, civil society actors and oversight bodies within and beyond Australia. ${ }^{36}$ These have shown that indefinite detention amounts to cruel and degrading treatment under the United Nations Convention against Torture and Other Cruel, Inhuman or Degrading Treatment or Punishment,${ }^{37}$ despite the High Court characterising it as non-punitive detention. ${ }^{38}$ A 2019 report by the Australian Human Rights Commission ('AHRC') found the increasing use of force in IDCs to have become 'especially restrictive and especially harsh', including the use of handcuffs for people to attend court or medical appointments. ${ }^{39}$ High rates of self-harm and despair attest to a mental health crisis in IDCs which has been documented in the medical research over a 20 -year period. ${ }^{40}$ This is often compounded by previous experiences of loss, displacement and trauma. In short, the design, operations, experiences and management of IDCs reflect a punitive intention which has come to be disavowed by law, irrespective of IDC conditions and the indefiniteness of punishment.

\section{B Residential Aged Care Facilities}

Aged care encompasses a range of services for non-Indigenous Australians over the age of 65, and for Indigenous Australians aged 50 and over, who cannot live independently. Care can be provided either at home, or in RACFs. RACFs provide accommodation, 'hotel' style services and facilities, nursing and some health support in dedicated sites. RACF providers include not-for-profit, private

Option for Refugees', SBS News (online, 25 February 2021) <https://www.sbs.com.au/news/they-arehuman-beings-released-medevac-detainees-call-for-permanent-resettlement-option-for-refugees $>$. nations/6926032>; Andreas Schloenhardt, 'Deterrence, Detention and Denial: Asylum Seekers in Australia' (2002) 22(1) University of Queensland Law Journal 54, 55;

37 Opened for signature 10 December 1984, 1465 UNTS 85 (entered into force 26 June 1987).

38 Al-Kateb v Godwin (2004) 219 CLR 562, 572 [45], 577 [61] (McHugh J), 636 [263] (Hayne J), 645-6 [291], 648 [297]-[298] (Callinan J); Minister for Immigration and Multicultural and Indigenous Affairs $v$ Al Khafaji (2004) 219 CLR 664, 678 [45] (Callinan J).

39 See, eg, Australian Human Rights Commission, Risk Management in Immigration Detention (Report, 2019) 29, and Australian Human Rights Commission, Use of Force in Immigration Detention (Report No 130, 2019).

40 See, eg, Zachary Steel and Derrick M Silove, 'The Mental Health Implications of Detaining Asylum Seekers' (2001) 175(11) Medical Journal of Australia 596, 598; Zachary Steel et al, 'Psychiatric Status of Asylum Seeker Families Held for a Protracted Period in a Remote Detention Centre in Australia' (2004) 28(6) Australian and New Zealand Journal of Public Health 527, 532-3; Kyli Hedrick et al, 'Temporal Variations in the Distribution of Self-Harm Episodes and Methods across the Australian Asylum Seeker Population: An Observational Study’ (2020) 17(8) PLoS Medicine e1003235. 
and government providers. ${ }^{41}$ As at June 2019, there were 873 organisations delivering residential aged care services across 2,717 sites, with $41 \%$ of these being private providers. ${ }^{42}$ The remainder are delivered by religious and charitable organisations and a very small percentage $(4 \%)$ by states, territories and local governments. ${ }^{43}$ The sector receives $\$ 13$ billion in government payments. ${ }^{44}$ Between 2017 and 2018, 7\% of all Australians aged 65 or over were receiving support in RACFs. ${ }^{45}$ Approximately half of those in RACFs are diagnosed with dementia. ${ }^{46}$

Although charitable, religious and state bodies have long provided aged care services, the Aged Care Act 1997 (Cth) heralded significant changes to funding arrangements and introduced an accreditation system for the sector. ${ }^{47}$ The Act introduced a new, privatised funding model, leading to a rapid increase in the number of for-profit providers. The accreditation process requires that all funded RACFs meet the quality standards of the Aged Care Quality and Safety Commission Act 2018 (Cth) ${ }^{48}$

The federal government has responsibility for 'regulation and policy oversight' and compliance with quality standards in aged care. ${ }^{49}$ State and territory governments are responsible for the assessment of aged care places, through Aged Care Assessment Teams, and fund some services directly, though this is largely borne by the Commonwealth. ${ }^{50}$ The Aged Care Approvals Round is a competitive process in which providers apply for approval to deliver government-funded places. Providers are required to ensure that all care and services meet the care needs of residents, comply with resident care plans and meet aged care standards

Productivity Commission (Cth), Report on Government Services 2020 (Report, 23 January 2020) 14.2 [14.1] < https://www.pc.gov.au/research/ongoing/report-on-government-services/2020/communityservices/aged-care-services $>$.

Department of Health (Cth), 2018-19 Report on the Operation of the Aged Care Act 1997 (Report, 27

November 2019) 44-5 <https://www.gen-agedcaredata.gov.au/www_aihwgen/media/ROACA/2018-19ROACA.pdf>.

43 Ibid 45.

44 Ibid 45-6.

45 'Aged Care', Australian Institute of Health and Welfare (Web Page, 11 September 2019)

<https://www.aihw.gov.au/reports/australias-welfare/aged-care>. As at 30 June 2019, the sector comprised 223,041 places in approved residential care - a mix of permanent and respite care - which is the largest component of the total aged care system: at 4,11 .

Ibid 8 . The most recent report by the Minister gives no indication of the numbers of those under the age of 65 in RACFs, although 3\% of entries into residential aged care have been reported as people aged under 65 in RACFs: at figure 1. The greater vacancy rate in RACFs as compared to National Disability Insurance Scheme ('NDIS') Specialist Disability Accommodation means that RACFs are 'the provider of last resort ... to people with high physical support needs under the NDIS': Summer Foundation,

Submission to Royal Commission on Aged Care Quality and Safety (August 2019) 4

$<$ https://www.summerfoundation.org.au/wp-content/uploads/2019/09/Younger-People-in-ResidentialAged-Care-web.pdf>.

47 For an overview of the history of the Australian aged care system, see Carolyn Smith, 'Navigating the Maze: An Overview of Australia's Current Aged Care System' (Background Paper No 1, Royal

Commission into Aged Care Quality and Safety, 25 February 2019)

$<$ https://agedcare.royalcommission.gov.au/publications/background-papers $>$.

49 Productivity Commission (Cth) (n 41) 14.2 [14.1].

50 Ibid. 
detailed in the Quality of Care Principles 2014 (Cth), and can lose funding or face sanctions for breaches. ${ }^{51}$

Although the legislative framework for RACFs is centred on consumer 'choice', this 'choice' remains highly constrained by legal and social conditions. ${ }^{52}$ For example, the 'choice' by residents to enter RACFs is often (though not always) made by the individual and/or their family in a context of crisis - such as after a hospital admission - because there are only limited supports for them to remain in the community or they are considered victims of or at risk of violence and neglect. For many, notably those living with dementia or other cognitive impairment or psychosocial disability, decisions to move to RACFs are not made by the individuals themselves but are instead made by a substitute decision-maker pursuant to guardianship laws or informally by family members. Accordingly, many individuals are living in RACFs against their preferences and sometimes even non-consensually. ${ }^{53}$ While courts have determined that specific individuals have been unlawfully detained in RACFs,${ }^{54}$ the design and operation of RACFs can lead to confinement of people irrespective of the legal terms on which they are living there, including locks and keypads on doors, locked gates, high fences, and separate dementia wards. ${ }^{55}$

The Aged Care Quality and Safety Commission was established in January 2019 to provide more robust oversight of the sector. Advocacy is funded by the federal government through the National Aged Care Advocacy Program ('NACAP') and provided by the Older Persons Action Network ('OPAN'). ${ }^{56}$ Despite these mechanisms, the Royal Commission has reported significant failures, systemic abuse and neglect. Such revelations are not new and are typically associated with use of restrictive practices and the nature of the settings themselves. In its 2019 report on the Aged Care Act 1997 (Cth), the Minister reported 5,233 'notifications of reportable assaults' including alleged or suspected physical assault and unlawful sexual assault or contact, with 55 sanctions issued

51 Aged Care Act 1997 (Cth) ch 4; Aged Care Quality and Safety Commission Act 2008 (Cth) pt 7B.

52 For a discussion of the problematic notion of 'choice' in aged care admissions, see Poland Lai, 'Regulation of "Care" in Long-Term-Care Homes in Ontario' in Katie Aubrecht, Christine Kelly and Carla Rice (eds), The Aging-Disability Nexus (University of British Columbia Press, 2020) 145.

53 Judy Allen and Tamara Tulich, "II Want to Go Home Now": Restraint Decisions for Dementia Patients in Western Australia' (2007) 33(2) Law in Context 1-2, 7-10.

54 See, eg, Public Advocate v C, B (2019) 133 SASR 353.

55 See, eg, Steele et al, 'Human Rights and the Confinement of People Living with Dementia in Care Homes' (n 18); Steele et al, 'Questioning Segregation of People Living with Dementia in Australia' (n 18) 6. See also Fiona McKenzie, 'The Government Needs to Stop Illegal Detention of Older People', The Age (online, 13 December 2020) <https://www.theage.com.au/national/victoria/the-government-needs-tostop-illegal-detention-of-older-people-20201213-p56n0f.html>.

56 'The Australian Government funds the National Aged Care Advocacy Program ('NACAP') which provides free, confidential and independent advice to consumers, their families and carers. Since 1 July 2017, NACAP has been delivered by a single national provider, the Older Persons Advocacy Network (OPAN)'. Department of Health (Cth) (n 42) 19. 
against 36 aged care providers. ${ }^{57}$ The Royal Commission in its Interim Report on the current state of RACFs noted the systemic harms in the system:

The Royal Commission has heard compelling evidence that the system designed to care for older Australians is woefully inadequate. Many people receiving aged care services have their basic human rights denied. Their dignity is not respected and their identity is ignored. It most certainly is not a full life. It is a shocking tale of neglect. ${ }^{58}$

Recently, based on reported experiences in a survey, the Royal Commission has estimated that $39.2 \%$ of RACF residents experience elder abuse (defined as emotional abuse, physical abuse and/or neglect; the estimate does not include financial abuse, social abuse and sexual abuse). ${ }^{59}$ In addition - unlike Australia several state signatories to the Optional Protocol to the Convention against Torture and Other Cruel, Inhuman or Degrading Treatment or Punishment ('OPCAT'), ${ }^{60}$ such as New Zealand, recognise that aged care in institutional settings can be characterised as 'places of detention' in which individuals can be deprived of their liberty and autonomy. For these reasons, we argue that despite their differences, both IDCs and RACFs are sites of confinement and segregation, and places of structural harm for marginalised populations.

\section{COVID-19 MEASURES, DISPOSABILITY AND STRUCTURAL HARMS ACROSS SITES OF CONFINEMENT}

The pandemic has made visible the already-existing failures and limits of the regulatory regimes for IDCs and RACFs and has drawn attention to the underlying structural harms of, and produced vulnerabilities for people living in, closed, congregated settings. We argue that the harms of the virus are appreciable as an effect of the circumstances of being confined, in which a person's vulnerability

57 Ibid 82, 84. As at 30 June 2019, 25 of these were still in place: at 82 . The overwhelming majority of these sanctions related to a failure to meet quality standards, including by St Basil's home in Randwick and 15 of the facilities run by the BUPA group, one of the largest providers in the sector: at $83,95-6,99$.

58 Royal Commission into Aged Care Quality and Safety (Interim Report, 31 October 2019) vol 1, 12. These observations align with recognition of human rights abuses in RACFs, as emphasised by the United Nations Special Rapporteur on the Rights of Persons with Disabilities. 'Many of these facilities are in fact segregated institutions, where staff exercise control over the person's daily life and make decisions about the person's care, including their placement in segregated locked wards, the administration of chemical restraints such as psychotropic drugs and the use of other physical restraints': Catalina Devandas-Aguilar, Report of the Special Rapporteur on the Rights of Persons with Disabilities, UN Doc A/74/186 (17 July 2019) 12 [32].

59 Royal Commission into Aged Care Quality and Safety, 'Experimental Estimates of the Prevalence of Elder Abuse in Australian Aged Care Facilities' (Research Paper No 17, December 2020) 1. See also Royal Commission into Aged Care Quality and Safety (Interim Report, 31 October 2019). See also research by Human Rights Watch on widespread use of chemical restraint in Australian RACFs: Human Rights Watch (n 15). See also research on the prevalence of sexual assault in RACFs: Smith et al (n 15).

60 Optional Protocol to the Convention against Torture and Other Cruel, Inhuman or Degrading Treatment or Punishment, opened for signature 18 December 2002, 2375 UNTS 237 (entered into force 22 June 2006). See also Laura Grenfell, 'Aged Care, Detention and OPCAT' (2019) 25(2) Australian Journal of Human Rights 248; New Zealand Human Rights Commission, 'The OPCAT and What It Can Do for Aged Care in New Zealand' (2 June 2016) Türangawaewae <https://www.hrc.co.nz/news/opcat-andwhat-it-can-do-aged-care-new-zealand/>. 
both now, and pre-COVID-19, is produced by the conditions of the site in which they reside. The initial stage of the pandemic offered an opportunity for governments to re-think detention, segregation and confinement towards both older people living in RACFs and asylum seekers or other detained non-citizens incarcerated in IDCs. Instead, COVID-19 measures adopted across both sites of confinement have intensified these produced vulnerabilities and exposed both populations to greater harms. Not only did these measures fail to protect people in IDCs and RACFs, these measures have increased, and may continue to increase, the likelihood of people within sites of confinement being exposed to, or contracting, COVID-19. Consequently, we suggest these COVID-19 measures reflected a broader positioning of both groups as 'disposable' populations. This position assumes that certain lives have different value, ought to be subject to less protection and considered less 'grievable' if their lives are lost. ${ }^{61}$ In this Part, we demonstrate how key COVID-19 measures adopted across both sites - despite purportedly being to 'protect' and care for people within each site - articulated such a logic of disposability towards people in IDCs and RACFs.

This logic of disposability is articulated differently between the two sites. While the lives of people confined to RACFs are predominantly understood with reference to the family as the principal social institution that gives their life meaning and inclusion within society, people in IDCs are, in contrast, understood vis-à-vis their purported exclusion from the Australian nation. ${ }^{62}$ These understandings have the potential to affect public perceptions of the injustice of particular COVID-19 measures in sites of confinement. In RACFs, social isolation and institutionalisation is framed as delivering a social good to residents, through access to care and support within a purportedly protective, benevolent setting. In the latter, detention is understood as a necessary response to those who are deemed to lack political and legal membership, in which the people detained are effectively punished for their own presence in Australia as unauthorised or criminalised bodies. Interestingly, despite these differences, the COVID-19 measures at times implicitly treated both groups of people across these distinct sites of confinement as 'risky' subjects: in the case of immigration detainees, a threat to national security to the Australian nation; and in the case of older people, as a possible infection risk to the Australian public more generally and a drain on hospital resources. ${ }^{63}$ Such positionings are important, as they not only shape and sustain

61 See Judith Butler, Precarious Lives: The Powers of Mourning and Violence (Verso, 2004) 32. See also Zygmunt Bauman, Wasted Lives: Modernity and Its Outcasts (Polity Press, 2004); the 'Deathscapes' project for documentation of lives lost in immigration detention under Australia's border 'protection' policy: Deathscapes (2016-20): Mapping Race and Violence in Settler States (Web Page, 2017) $<$ https://www.deathscapes.org/>. For a detailed analysis of this in the context of Australia's immigration detention policy, see Paul Hodge, 'A Grievable Life? The Criminalisation and Securing of Asylum Seeker Bodies in the "Violent Frames" of Australia's Operation Sovereign Borders' (2015) 58 Geoforum 122.

62 See generally Nikolas Rose, 'Government and Control' (2000) 40(2) British Journal of Criminology 321. This understanding of people in IDCs persists despite the fact that many people in IDCs have Australian family members or strong social and economic ties to people in the Australian community.

63 See also discussion in a Canadian context of the positioning during COVID-19 of migrants as 'a risk' rather than 'at risk', resulting in a focus on policing their admission at the border, rather than their health needs within the state: Y Y Brandon Chen, 'Migrant Health in a Time of Pandemic: Fallacies of Us- 
legal regimes of care, control and confinement, but also determine how these populations and practices are understood and valued in the public imagination and by political leadership.

Already in the early stages of the pandemic, both international and domestic public health advice emphasised the necessity of careful, targeted preventative measures in closed settings since being in enclosed, confined spaces generates vulnerability to the virus. In April 2020, the World Health Organization ('WHO') recommended that all states take steps to prevent and minimise outbreaks in 'highvulnerability settings' such as RACFs where individuals were at greater risk, both due to confinement and prior medical conditions. ${ }^{64}$ It also called for countries to prioritise COVID-19 diagnostic testing of 'vulnerable populations who are at risk of developing severe disease' in closed settings. ${ }^{65}$ Similarly, in the same month, the United Nations High Commissioner for Refugees ('UNHCR') called for the immediate release of refugees and asylum seekers from closed detention, and advocated enhanced hygiene and infection control measures, especially in crowded living conditions. ${ }^{66}$ As global COVID-19 infection rates surpassed 15 million in late July 2020 , UNHCR reiterated this call. ${ }^{67}$

Although federal and state governments quickly adopted a range of measures to stem the spread of COVID-19 in the Australian community after Australia's first positive case in late January, ${ }^{68}$ measures adopted across sites of confinement were much more limited. In the context of IDCs, the federal government has not only resisted any calls to release detainees, it has revealed a steadfast commitment to detaining people regardless of this risk. ${ }^{69}$ Similarly, in RACFs, there has been an apparent unwillingness to take action beyond that which is little more than the

Versus-Them' in Colleen M Flood et al (eds), Vulnerable: The Law, Policy and Ethics of COVID-19 (University of Ottawa Press, 2020) 407, 409.

64 World Health Organization, COVID-19 Strategy Update (Report, 14 April 2020) 10

$<$ https://www.who.int/publications/i/item/covid-19-strategy-update---14-april-2020>.

65 Ibid 9-10.

66 United Nations High Commissioner for Refugees, 'Global COVID-19 Emergency Response' (Factsheet, 9 April 2020)

$<$ https://reliefweb.int/sites/reliefweb.int/files/resources/09042020_UNHCR\%20Global\%20COVID19\%20Emergency\%20Response.pdf>.

67 United Nations High Commissioner for Refugees, 'UNHCR Stresses Urgent Need for States to End Unlawful Detention of Refugees and Asylum-Seekers, amidst COVID-19 Pandemic' (Press Release, 24 July 2020) < https://www.unhcr.org/en-au/news/press/2020/7/5f1569344/unhcr-stresses-urgent-needstates-end-unlawful-detention-refugees-asylum.html>.

68 Australia's first case of COVID-19 was announced on 25 January 2020: Greg Hunt, 'First Confirmed Case of Novel Coronavirus in Australia' (Media Release, Department of Health (Cth), 25 January 2020) $<$ https://www.health.gov.au/ministers/the-hon-greg-hunt-mp/media/first-confirmed-case-of-novelcoronavirus-in-australia $>$. The range of governmental measures introduced included voluntary and then compulsory quarantine for returning travellers; imposed travel restrictions, including within local neighbourhoods; and advocated the use of sanitisers in public spaces and personal protective equipment in hospitals and health care services. Schools were shut down, shifting to online classes and workers were advised to work from home wherever this was possible: See, eg, NSW Government, 'COVID-related Legislation', NSW Legislation (Web Page, 26 February 2021)

$<$ https://www.legislation.nsw.gov.au/information/covid19-legislation>.

69 Anthea Vogl et al, 'COVID-19 and the Relentless Harms of Australia's Punitive Immigration Detention Regime' (2021) 17(1) Crime, Media, Culture 43. 
minimum standards set out for infection prevention and control. ${ }^{70}$ Even as the number of COVID-19 cases increased in RACFs and arrangements were made by some facilities to transport residents to hospitals, there was a reluctance by some RACFs, and even by the federal government, to support such transfers (commonly referred to as 'decanting'). ${ }^{71}$ Instead, the preference was that residents remain in RACFs to be cordoned 'into distinct sections of the home', maintaining a separation between residents who tested positive, and those with negative test results. $^{72}$ This reluctance has been a significant contributor to the number of COVID-19 related deaths in RACFs, in part because RACFs were ill-equipped to give effect to this. As of December 2020, those living in RACFs comprise one per cent of the Australian population, and yet 74.6 per cent of all COVID-19 deaths, most of these in Victoria which also has the highest rate of admissions to permanent RACFs. ${ }^{73}$ Notwithstanding the comorbidities endured by those in aged care, such a figure is alarming, especially given that some RACFs managed to contain the spread of the virus through attentive planning: many deaths were avoidable.

Moreover, across IDCs and RACFs, COVID-19 measures have intensified experiences of social isolation, through implementing prohibitions on external visitors. In IDCs, the visitor program to detainees ceased on 24 March 2020 and additional steps were taken to prohibit people from delivering food, gifts, or other items to people in Victorian IDCs. ${ }^{74}$ This has effectively imposed social isolation on detainees. Further government attempts to seize mobile phones, based on the dubious claim by Federal Minister Alan Tudge that this will prevent access to

70 For such standards, see eg Communicable Diseases Network Australia, 'COVID-19 Guidelines for RACFs' (n 2).

71 On 'decanting', see, eg, Office for Aging Well (SA), COVID-19 Integrated Response Framework for the Management of Multiple Outbreaks in Residential Aged Care Facilities in South Australia (Guidelines, 25 November 2020) 14-15; Sandy Cheu, 'Hospitalising Residents with COVID under Spotlight', Australian Aging Agenda (online, 13 August 2020) < https://www.australianageingagenda.com.au/covid19/hospitalising-covid-positive-residents-under-national-spotlight/>.

72 The use of the term 'decanting' has itself been subject to criticism, since it degrades and dehumanises those in aged care. See, eg, the reported comments of federal Aged Care Safety and Quality commissioner Janet Anderson that the NSW policy of decanting was 'intolerable and unsupportable': Julie Power, 'COVID-19 Has Exposed Australia's Aged Care Sector's Flaws, Royal Commission Hears', The Sydney Morning Herald (online, 10 August 2020) <https://www.smh.com.au/national/covid-19-hasexposed-australia-s-aged-care-sector-s-flaws-royal-commission-hears-20200810-p55k $7 \mathrm{p} . \mathrm{html}>$.

73 This figure was cited in the Senate Select Committee on COVID-19, Parliament of Australia, First Interim Report (Report, December 2020) xii $<$ https://parlinfo.aph.gov.au/parlInfo/download/committees/reportsen/024513/toc_pdf/Firstinterimreport. pdf;fileType=application\%2Fpdf $>$. This report also found the Federal Government to be responsible for significant failures, leading to deaths in aged care: at xix. See also Rick Morton, 'Covid-19 Outbreaks in Aged Care', The Saturday Paper (online, 25 July 2020)

$<$ https://www.thesaturdaypaper.com.au/news/health/2020/07/25/covid-19-outbreaks-agedcare/159559920010154>. These figures also reflect similar statistics in other jurisdictions: see, eg, Joseph Ibrahim, 'Ontario's Long-term Care COVID-19 Commission'(2020) 15(4) Residential Aged Care Communiqué 12. This report also provides detailed case studies and analysis of the impact of COVID-19 in residential aged care, in Australia and internationally.

74 COVID-19 and the Border: Immigration Detention', Department of Home Affairs (Web Page, 11 August 2020) <https://web.archive.org/web/20201015071511/https://covid19.homeaffairs.gov.au/immigrationdetention>. 
inappropriate internet sites and will 'ensure the safety of those in immigration detention facilities' ${ }^{75}$ would have further deprived people detained of their main form of contact with the outside world ${ }^{76}$ Such contact is critical not only for their wellbeing, but also offers a crucial avenue of information about COVID-19 protective measures in sites which are permeated by governmental secrecy. Detainees had forewarned the risk of infection since March 2020, reporting limited or no access to personal protective equipment ('PPE') and hand sanitiser, the failure of security guards to adhere to infection control guidelines, and the impracticality of observing social distancing in cramped living quarters and narrow hotel corridors. ${ }^{77}$ While there is to date no known case of a person in an IDC having contracted the virus, detainees continue to live with ongoing anxiety about the potential for infection and the institutional failure to do enough to protect them. ${ }^{78}$ This fear has been borne out in part, with two Serco guards testing positive within the initial period of Australia's confirmed cases of COVID-19. ${ }^{79}$ Despite this, the Department of Home Affairs has continued to refuse to mass release people from IDCs. An Ombudsman investigation has confirmed that the number of people in IDCs actually increased during the first four months of the pandemic in Australia (March-July 2020), in part owing to the temporary pause on deportations. ${ }^{80}$

Bans on visitors were also adopted in many RACFs. ${ }^{81}$ However, unlike the arrangements in IDCs, many RACF providers implemented alternative measures in order to maintain social contact, including 'window' visits, online contact and in some cases simply limiting visits to one person at a time. In consultation with

75 Commonwealth, Parliamentary Debates, House of Representatives, 14 May 2020, 3441 (Alan Tudge).

76 See Migration Amendment (Prohibiting Items in Immigration Detention Facilities) Bill 2020 (Cth). At the time of writing, while this Bill passed the House of Representatives, it was unable to obtain majority support in the Australian Senate.

77 Rebekah Holt and Saba Vasefi, “"We are Sitting Ducks for Covid 19”: Asylum Seekers Write to PM after Detainee Tested in Immigration Detention', The Guardian (online, 24 March 2020)

$<$ https://www.theguardian.com/australia-news/2020/mar/24/we-are-sitting-ducks-for-covid-19-asylumseekers-write-to-pm-after-detainee-tested-in-immigration-detention>.

78 James Hancock, 'Fears Not Enough Is Being Done to Protect Asylum Seekers in Melbourne Detention from Coronavirus', $A B C$ News (online, 2 August 2020) <https:/www.abc.net.au/news/2020-08-02/notenough-being-done-to-protect-asylum-seekers-from-coronavirus/12503618>.

79 Ben Smee, Ben Doherty and Rebekah Holt, 'Fears for Refugees after Guard at Brisbane Immigration Detention Centre Tests Positive for Coronavirus', The Guardian (online, 19 March 2020)

<https:/www.theguardian.com/australia-news/2020/mar/19/fears-for-refugees-as-guard-at-brisbaneimmigration-detention-centre-tests-positive-for-coronavirus $>$. In addition, a guard at Kangaroo Point Hotel detention site also contracted the virus, and a number of guards working at the Villawood detention centre had to self-isolate due to potential infection from the Sydney 'Crossroads Hotel' outbreak. See Matt Bungard and Rachel Eddie, 'Staff Stood Down at Villawood Detention Centre due to COVID-19 Concerns', The Sydney Morning Herald (online, 13 July 2020)

$<$ https://www.smh.com.au/national/nsw/staff-stood-down-at-villawood-detention-centre-due-to-covid19-concerns-20200713-p55box.html>.

80 Commonwealth Ombudsman, 'Statement by the Commonwealth Ombudsman Michael Manthorpe on the Management of COVID-19 Risks in Immigration Detention Facilities’ (Media Release, 1 July 2020)

81 Luke Henriques-Gomes, 'Some Australian Aged Care Homes Go beyond Official Coronavirus Advice with Lockdowns', The Guardian (online, 20 March 2020)

$<$ https://www.theguardian.com/world/2020/mar/20/some-australian-aged-care-homes-go-beyond-officialcoronavirus-advice-with-lockdowns $>$. 
the aged care sector, OPAN ${ }^{82}$ developed a code to 'provide an agreed industry approach to ensure [RACF] residents are provided the opportunity to receive visitors during the COVID-19 pandemic, while minimising the risk of its introduction to, or spread within, a residential care home'. ${ }^{83}$ However, the practice of preventing visits to residents was not adopted by all RACFs since some providers recognised the greatest risk to infection would likely come from the 'back door' (that is, the workforce) rather than from the 'front door' (that is, family and friends). ${ }^{84}$

Reflecting this, the greatest risk posed to those in IDCs and RACFs has been from the workforce which rotates in and out of these sites, many of whom work at multiple workplaces. The evidence of staff transmission and infection in RACFs and IDCs points to the disturbing contradiction between having a workforce to maintain a supposedly impenetrable site, and the contribution of that workforce to the porosity of these boundaries: ironically, the threat of infection is most likely to come from those who are there to maintain these places as secure and impermeable. ${ }^{85}$ Expert advice also warned that Australia's 'current aged care workforce will not have the skills to manage COVID-19, ${ }^{86}$

By late July 2020, the Victorian Branch President of the Australian Medical Association warned that the Victorian aged care sector was 'under [so much] pressure' that it 'will cause collapse and severe system stress' ${ }^{87}$ This warning in part pointed to the systemic problem of creating conditions for, and reliance upon, a highly insecure and mobile workforce: $60 \%$ of the aged care sector workforce

82 Older Persons Advocacy Network ('OPAN') is the key advocacy body funded by the Federal Government to represent the interests of older people and those in RACFs.

83 See Older Persons Advocacy Network, 'Industry Code for Visiting Residential Aged Care' (Guidelines, 11 May 2020) <https://opan.com.au/industry-code-finalised/>.

84 'Sydney Hearing 2' (Transcript No O/N H-1245083, Royal Commission into Aged Care Quality and Safety, 11 August 2020) P-8553 (Stephen Judd).

85 This concern has been emphasised by public interest and refugee advocacy organisations: see, eg, Public Interest Advocacy Centre, 'Re-opening Christmas Island Is a Cruel and Ineffective Response to the Threat of COVID-19 in Immigration Detention' (Media Release, 5 August 2020); 'COVID19 Outbreak Imminent Due to Australian Border Force Neglect of Public Health Measures in Melbourne Detention Centres', Asylum Seeker Resource Centre (Blog Post, 4 August 2020)

$<$ https://www.asrc.org.au/2020/08/04/covid19-outbreak-imminent-due-to-australian-border-forceneglect-of-public-health-measures-in-melbourne-detention-centres/>.

86 Lee-Fay Low, 'Report: COVID-19 in Nursing Homes and Policy Responses in Australia', LTC Responses to COVID-19 (Blog Post, 24 March 2020) <https://tccovid.org/2020/03/24/report-covid-19in-nursing-homes-and-policy-responses-in-australia/ $>$. For example, there was a dramatic decline of over $40 \%$ of staff who had to self-isolate due to infection or possible infection and there were no adequate plans to do so. Regular reporting on measures adopted in RACFs across the globe by London School of Economics, and the International Long-Term Care Policy Network stated that in practice, many of Australia's aged care providers do not have the workforce, expertise, PPE or systems to manage an outbreak': Adelina Comas-Herrera and Jose-Luis Fernandez-Plotka, 'Summary of International Policy Measures to Limit Impact of COVID-19 on People Who Rely on the Long-Term Care Sector' (Summary Paper, 30 March 2020) <https://tccovid.org/wp-content/uploads/2020/03/Summary-of-internationalpolicy-measures-to-limit-impact-of-COVID19-on-people-who-rely-on-the-Long-Term-Care-sector-30March-pm.pdf $>$.

87 Melissa Davey, 'Victoria's Aged Care System on Verge of Collapse amid Covid-19 Surge, Doctors Warn', The Guardian (online, 23 July 2020) < https://www.theguardian.com/australianews/2020/jul/23/victorias-aged-care-system-on-verge-of-collapse-amid-covid-19-surge-doctors-warn>. 
are casual or part-time workers, many of whom work across a number of facilities. ${ }^{8}$ Similarly, Serco engages a highly casualised workforce within Australia's immigration detention network, and subcontracts certain functions to separate firms like private security contractors. Two of the first COVID-19 related deaths in Australia are believed to have been caused by transmission from an infected staff member working in the Dorothy Henderson Aged Care Facility in Sydney. ${ }^{89}$

It is clear that persons detained or confined in IDCs or RACFs are exposed to risk by reason of the settings they inhabit. Those who are older and/or have preexisting medical conditions, like those in RACFs and IDCs, are therefore doubly exposed to the virus through the harms they undergo as an effect of confinement. Effectively all (99.7\%) of those living in RACFs have a pre-existing medical condition. ${ }^{90}$ Extensive and longstanding research also attests to compromised health as an effect of long-term detention of refugees and asylum seekers. ${ }^{91}$ Together with prisons, these sites are among the most risky places to be confined during a pandemic. Yet, the extent of planning to limit infection, together with appropriate action to prevent exposure, has fallen far short of the standards enjoyed by the general public for minimising risk. ${ }^{92}$ What is more, in both sites, there have been concerns about secrecy and lack of transparency. ${ }^{93}$

In response to criticisms, those responsible for services in RACFs and IDCs have defended their 'meticulous adherence to expert health advice' and commitment to strict infection control measures, in compliance with industry guidelines. ${ }^{94}$ Statements like these are hard to reconcile with high death rates in RACFs, and the evident failure of IDCs to ensure that those detained are equipped with what is required to meet the standards expected in the general community. This suggests a privileging of minimum procedural standards as a means of guaranteeing human rights (life, health and autonomy, for example), reducing COVID-19 response to a metrics of technical criteria; as a performance measurement or a 'tick the box' exercise, rather than the valuing of a person's life

88 Ibid.

89 Kevin Nguyen and Glen Moret, 'Third Coronavirus-Related Death in Australia after Man in His 80s Dies in Sydney Hospital', ABC News (online, 8 March 2020) < https://www.abc.net.au/news/2020-0308/coronavirus-related-death-in-sydney-hospital/12036410>.

90 'Australians Living in Residential Aged Care', Australian Bureau of Statistics (Web Page, 5 November 2018)

<https://www.abs.gov.au/AUSSTATS/abs@.nsf/Lookup/4430.0Main+Features1022015?OpenDocument $>$.

$91 \quad$ Steel and Silove (n 40) 598-9.

92 Angeline Ferdinand, Claire Loughnan and Philomena Murray, 'Refugees and Australia's Double Standards on COVID-19', Arena (online, 16 June 2020) <https://arena.org.au/refugees-and-australiasdouble-standards-on-covid-19/>.

93 Michelle Grattan, 'View from the Hill: There's No Case for Keeping Secret Any Aged Care Facility's COVID Details', The Conversation (online, 4 August 2020) $<\mathrm{https}$ ///theconversation.com/view-from-thehill-theres-no-case-for-keeping-secret-any-aged-care-facilitys-covid-details-143920>.

94 Biwa Kwan, 'Border Force Defends Handling of Coronavirus Risk as Global Report Points Finger at Australia's Asylum Seeker Treatment', SBS News (online, 17 July 2020)

$<$ https://www.sbs.com.au/news/border-force-defends-handling-of-coronavirus-risk-as-global-reportpoints-finger-at-australia-s-asylum-seeker-treatment $>$. 
and all that this entails. Given the lack of meaningful commitment to the rights of those in RACFs, it is unsurprising then that Australia at one stage had the 'second or third highest rate of death' in the world in RACFs. ${ }^{95}$

The social impacts are also severe. ${ }^{96}$ RACF resident, Merle Mitchell, gave evidence at the Royal Commission's COVID-19 hearings to say that under the lockdown she was restricted to her room, with no view, no visits from family and friends, no opportunities to go out into the community, and reduced opportunities for allied health and personal care services, saying that:

I know I'm here until I die, so every morning when I wake up I think 'Damn, I've woken up' but I'm here until I die, so I've got to make the best of it and that's what I try to do. Which is not to say that I'm not being cared for, but I am sure if you really asked most people here they would all say they would rather be dead rather than living here, if they're honest, that is. ${ }^{97}$

Likewise, people in IDCs have commented that they feel like 'sitting ducks' for COVID-19, held in 'potential death trap[s] in which we have no option or means to protect ourselves' ${ }^{98}$ Both sets of comments alert us to broader cultural acceptance of social isolation, segregation and confinement in both RACFs and IDCs, whether there is a pandemic or not. In particular, during the pandemic, there has been general acquiescence with the notion that people in RACFs are to be kept in, despite the reality that remaining in RACFs had not only been a health risk but also could led to avoidable deaths. Finally, both sets of comments provide the public with insights into the lived experiences of people in IDCs and RACFs. This is particularly so for RACFs as much of the media reporting during the pandemic on RACFs during the pandemic has been from the perspective of families rather than residents (thus being a missed opportunity to recognise their agency) ${ }^{99}$

At the heart of such COVID-19 measures, we argue, is a logic of disposability that is used to limit people's enjoyment of fundamental human rights (like freedom of mobility and access to healthcare) while also constructing both groups as risky and burdensome. While those in IDCs have long been framed by government and media in Australia as a border security risk and a burden on economic wellbeing

95 Elias Visontay, 'Hundreds of Australia's Aged Care Residents Will Die of Covid because of Government Failure, Expert Warns', The Guardian (online, 12 August 2020) <https://www.theguardian.com/australianews/2020/aug/12/australias-covid-aged-care-deaths-worst-disaster-that-is-still-unfolding-before-myeyes>.

96 Bethany Brown and Kim Samuel, 'Blanket Visitor Ban under COVID-19 Will Do More Harm than Good', Human Rights Watch (Web Page, 8 April 2020)<https:/www.hrw.org/news/2020/04/08/blanketvisitor-ban-under-covid-19-will-do-more-harm-good $>$.

97 'Sydney Hearing 2' (Transcript No O/N H-1245082, Royal Commission into Aged Care Quality and Safety, 10 August 2020) P-8409 (Merle Mitchell). See also her interview with Fran Kelly: 'Balancing the Rights of Aged Care Residents with Broader Public Health Concerns', RN Breakfast with Fran Kelly (ABC Radio, 12 August 2020) <https://www.abc.net.au/radionational/programs/breakfast/balancing-therights-of-aged-care-residents-with-public-health/12548498>.

98 Holt and Vasefi (n 77).

99 As Carole Cox has commented, 'Ageism perpetuates negative stereotypes that describe older people as frail with diminished status creating burdens on society, [and that] have been spread by media in many countries. Such attitudes and beliefs undervalue the contributions of older adults and may even impact access to services and supports, particularly when resources are scarce': Carole Cox, 'Older Adults and Covid 19: Social Justice, Disparities, and Social Work Practice' (2020) 63(6-7) Journal of Gerontological Social Work 611, 612. 
of citizens, the reluctance by the aged care sector to provide care commensurate with the preservation of life, likewise shows a regarding of certain lives as inevitably less worthy, together with the notion that they might pose a health risk to the community should they be moved to a hospital setting and be a burden on hospital resources. ${ }^{100}$ The reluctance to 'decant' RACF residents to hospitals itself an offensive term which reduces people in RACFs to an object - has been described as a decision to minimise risk to others and to potentially alleviate the burden on the hospital system. ${ }^{101}$ Both groups of people are seen as separate to or distinct from the general population such that they require - while often being denied - separate COVID-19 protective measures. Yet, some of these key measures, rather than actually offering protection, have also intensified their social isolation and material risk of infection. This reveals an underlying tension between social commitments to the flourishing of productive bodies of the population at large deemed eligible for national resources and human rights and other people who are treated, in Bauman's terms, as 'human waste' on the path to death. ${ }^{102}$

Regardless of whether their lives are treated as less worth of protection and safety, such measures suggest the deaths of people in IDCs and RACFs are ultimately considered more socially acceptable or less grievable. Drawing on Judith Butler, who reflects on the grief and mourning for some lives, and not others, post-9/11, ${ }^{103}$ we question the acceptance of the death of some and the grievability of others in pandemic times. ${ }^{104}$ While those living in RACFs have formal political status, their lives are managed as lives which are already on the path to death or as the 'socially dead'. ${ }^{105}$ The evident unwillingness by

100 This reflects observations made by the Special Rapporteur on the Rights of Persons with Disabilities, contrasting ableism with ageism: 'Although ageism and ableism share common roots and consequences, inequality in older age is not the mere result of ableist biases. Ageism - the stereotyping of, and prejudice and discrimination towards, older people and older age - is a distinct form of oppression that affects older persons, including older persons with disabilities. Older persons are often perceived as a burden, dependent, unproductive, undeserving or helpless. While disability is increasingly understood as a social construct, inequalities due to old age are predominantly seen as "natural" or "inevitable"": DevandasAguilar (n 58) 5 [7].

101 On the decision of whether or not to transfer people from aged care to hospitals, including some benefits of remaining in aged care, see Jed Montayre and Richard Lindley, 'Should All Aged-Care Residents with COVID-19 Be Moved to Hospital? Probably, But There Are Drawbacks Too', The Conversation (online, 7 August 2020) <https://theconversation.com/should-all-aged-care-residents-with-covid-19-be-moved-tohospital-probably-but-there-are-drawbacks-too-143826>.

Bauman (n 61).

103 Butler (n 61) 22, 29-30.

104 Judith Butler and George Yancy, 'Interview: Mourning is a Political Act Amid the Pandemic and Its Disparities (Republication)’ (2020) 17(4) Journal of Bioethical Inquiry 483.

105 On a foundational theorisation of the concept of 'social death', see Orlando Patterson, Slavery and Social Death: A Comparative Study (Harvard University Press, 1982). For more contemporary iterations and uses of the concept, see Jana Králová, 'What is Social Death?' (2015) 10(3) Contemporary Social Science 235; E Borgstrom, 'Social Death’ (2017) 110(1) QJM: An International Journal of Medicine 5. This 'social death' is rendered even more apparent for those in RACFs who are living with dementia: 'People living with dementia are profoundly dehumanised. They are positioned outside of full personhood by reason of social norms associated with continuity over the life-course of memory, cognition and personality. Given that dementia is associated with old age, social norms of youthfulness compound with norms of cognitive ability. When people living with dementia are perceived as failing to meet these norms, they are dehumanised in a very particular way: by being associated with waste and 
governments and their agencies to deliver the same protections as those enjoyed in community to people in IDCs and RACFs discloses a preparedness to dispense with some lives in order to commit to other lives. This can be understood as an exercise in 'scientific racism' or social eugenics, ${ }^{106}$ a way of classifying lives which is redolent of the eugenics of colonial Australian policies. However, it has also been driven by the austerity practices which have intensified with the pandemic. ${ }^{107}$ It was clear that choices were made about whose lives to protect and save in the face of potentially limited medical resources to do so. ${ }^{108}$

The lower standard of COVID-19 protection in IDCs and RACFs is particularly problematic, given the lethal force of the pandemic and the 'hidden assumptions' of healthcare systems in terms of who is entitled to proper treatment and care. ${ }^{109}$ A significant cohort of people in APODs were refugees evacuated to Australia from Papua New Guinea and Nauru for medical reasons, who were already barely getting the medical care they need, if any. ${ }^{110}$ Moreover, the

death. The association between dementia and death is evident in representations of people living with dementia as "effectively dead" or "zombies" - inhabitants of a liminal zone between life and death. Media and popular culture contribute to degrading and dehumanising understandings of people living with dementia through references to dementia crises and financial burdens of care or "apocalyptic demographic discourse", which can be exacerbated by neoliberal efficiency and profit-driven approaches to dementia care': Linda Steele et al, 'Ending Confinement and Segregation: Barriers to Realising Human Rights in the Everyday Lives of People Living with Dementia in Residential Aged Care' (2020) Australian Journal of Human Rights (advance) 15. See also Alisa Grigorovich and Pia Kontos, 'COVID19, Stigma and the Scandalous Neglect of People Living with Dementia', The Conversation (online, 5 August 2020) <https://theconversation.com/covid-19-stigma-and-the-scandalous-neglect-of-peopleliving-with-dementia-140817>.

106 Michel Foucault, 'Lecture 17 March 1976' in M Bertani \& A Fontana (eds), Society Must be Defended, tr D Macey (Penguin Books, 1997) 239.

107 As noted in Colleen M Flood et al, 'Overview of COVID-19: Old and New Vulnerabilities' in Colleen M Flood et al, Vulnerable: The Law, Policy and Ethics of COVID-19 (University of Ottawa Press, 2020) 1, 13: "The pandemic is not a natural disaster or an "act of God". The effects of COVID-19 are the result of choices: to tax and spend in ways that benefit some and disadvantage others; to intervene or not intervene in the economy when market forces prevent individuals from meeting basic needs; to regulate in particular ways; to view health as the product of a combination of luck and personal choices rather than the product of colliding social, economic, and political factors.'

108 This reflects a pattern seen elsewhere. As one doctor remarked in response to resource scarcity in the Lombardy region in Italy: 'We have to decide who must die and whom we shall keep alive': Lisa Rosenbaum, 'Facing Covid-19 in Italy: Ethics, Logistics, and Therapeutics on the Epidemic's Front Line' (2020) 382(20) New England Journal of Medicine 1873, 1874. Research conducted amongst medical staff in Italy indicated that as difficult as this was, decisions had to be made about delivery of health care based on the likelihood of a life being saved. Inevitably, at a time of scarce resources, a person's 'stage of life' was a key consideration: at 1875 . Elsewhere, a Texas governor remarked that grandparents should be 'willing to risk death' for the sake of the economy: KM Seethi, 'A “Testing Time" for Ageing: Geronticide or Necropolitics?', Countercurrents (online, 8 April 2020) $<$ https://countercurrents.org/2020/04/a-testing-time-for-ageing-geronticide-or-necropolitics/>.

109 See Hamish Robertson and Joanne Travaglia, 'The Necropolitics of COVID-19: Will the COVID-19 Pandemic Reshape National Healthcare Systems?', London School of Economics (Blog Post, 18 May 2020) <https://blogs.lse.ac.uk/impactofsocialsciences/2020/05/18/the-necropolitics-of-covid-19-will-thecovid-19-pandemic-reshape-national-healthcare-systems/ $>$.

110 See Michael Green, 'Playing Games with Us: The Medevac Men Languishing in Hotel Detention', The Guardian (online, 15 December 2020) $<$ https://www.theguardian.com/australianews/2020/dec/15/playing-games-with-us-the-medevac-men-languishing-in-hotel-detention-for-almost- 
Department of Home Affairs' decision to re-open the remote Christmas Island IDC in the height of the pandemic and transfer anyone seen to be at particular risk of COVID-19 away from metropolitan IDCs located on the east coast of Australia shows a willingness to intensify existing practices of physical segregation and social isolation. ${ }^{111}$

Finally, this logic of disposability is shown through the lack of any institutional responsibility to date for the failures of protection, in particular the high death rates in RACFs. Largely, to date, state and federal governments have declared their sympathy to affected individuals or surviving family members while avoiding legal or social responsibility. ${ }^{112}$ In this reluctance to take responsibility for those in IDCs or RACFs, these individuals become the uncounted, whose lives and whose deaths are not at the forefront of public concern. The inability of the Minister for Aged Care, Richard Colbeck, to readily provide the Royal Commission with figures on the deaths in aged care reflects a political amnesia of the older dead. The failure to properly remember these deaths can be seen as symptomatic of a prior erasure of their lives. Soon after, the comments by former Australian Prime Minister Abbott that the deaths of some should be accepted in order to open up a space for renewed economic activity reveals the furtive logic of casting some populations as economically 'excessive' or 'redundant'. ${ }^{113}$ It is not simply that Abbott is rejecting the notion of saving lives at all costs, but that his comments target the lives of those deemed to be economically (and physiologically) less worthy. For those in IDCs, this disregard is shown through government attempts to silence and erase people in IDCs from public view, an aim that has been difficult to realise in the face of sustained vocal public protests drawing attention to the 'active neglect' of people in APODs in particular. ${ }^{114} \mathrm{We}$

two-years>; Refugee Action Collective (Vic), 'Support Grows to Say: Free the Refugees' (Media Release, 8 January 2021).

111 Hannah Ryan, 'Australian Government to Reopen Christmas Island Detention Centre during Covid-19 Crisis', The Guardian (online, 5 August 2020) <https://www.theguardian.com/australianews/2020/aug/04/australian-government-to-reopen-christmas-island-detention-centre-during-covid-19crisis $>$.

112 Peter Hartcher, 'Everyone Is Sorry, No One Is Responsible: COVID Exposes Lack of Ministerial Accountability', The Age (online, 28 August 2020)

$<$ https://www.theage.com.au/politics/federal/everyone-is-sorry-no-one-is-responsible-covid-exposeslack-of-ministerial-accountability-20200828-p55qdt.html>. For example, the Federal Government's National Guidelines on Aged Care released in March 2020 stated that the "primary responsibility of managing COVID-19 outbreaks lies with the RCF, in their responsibility for resident care and infection control; all RCF should have access to infection control expertise, whether in-house or not, and outbreak management plans in place': Communicable Diseases Network Australia, 'COVID-19 Guidelines for RACFs' (n 2) 2. It added that such responsibility might extend to 'caring for residents who would usually be managed in the hospital setting'.

113 Bauman (n 61) 5.

114 See, eg, 'Protests as Asylum Seekers Are Moved between Hotels', The Age (online, 17 December 2020) $<$ https://www.theage.com.au/national/victoria/protests-as-asylum-seekers-are-moved-between-hotels20201217-p56ofx.html>. On the concept of 'active neglect' vis-à-vis Australia's treatment of refugees, see Claire Loughnan, 'Active Neglect: The New Tool for the "Externalisation" of Refugee Protection', Border Criminologies (Blog Post, 16 July 2019) <https://www.law.ox.ac.uk/research-subjectgroups/centre-criminology/centreborder-criminologies/blog/2019/07/active-neglect>. 
now turn to consider whether legal advocacy can challenge the structural harms and disposability in IDCs and RACFs laid bare during COVID-19.

\section{COVID-19 LEGAL ADVOCACY ACROSS SITES OF CONFINEMENT}

This section traces legal advocacy in the form of strategic litigation and class actions in response to COVID-19 initiated by or on behalf of people in sites of confinement themselves. To date, legal actions across both sites of confinement have principally relied upon claims of negligence ${ }^{115}$ to either compel protective action from the executive (in the case of IDCs) or seek corporate accountability for COVID-related deaths and other harms from private organisations (in the case of RACFs). As our analysis demonstrates, a key distinction between the strategic litigation and class actions so far is that the RACF class actions have been largely reactive (initiating legal actions once COVID-related deaths have occurred) while the legal proceedings in the IDC context have sought to be preventive and proactive in focusing on removing people from IDCs in order to prevent any COVID-related deaths. This has several important legal implications including determining the possible legal remedy (that is, injunctive relief in IDCs in contrast to damages for mental harm in RACFs); framing legal subjects of harm (that is, people detained in IDCs themselves taking action in contrast in the RACF context to a more expansive plaintiff group including family members of deceased residents and RACF staff); and shaping subsequent state responses to the particular politics of care across both sites.

\section{A Strategic Litigation and Class Actions: A Legal Duty to Care?}

Strategic litigation has been defined as a powerful advocacy tool which can advance human rights accountability. ${ }^{116}$ Although typically initiated by an individual plaintiff, a core aspect of strategic litigation is 'its intention to have effects beyond that of the individual litigant bringing the case'. ${ }^{117}$ Accordingly, while some strategic litigation cases seek to set a new legal precedent, more often strategic litigation uses well-established legal principles as 'tools' to advance legal and extralegal outcomes for a wider affected population. These can include compelling a specific action that affects a class of persons in general, promoting disclosure or transparency from a particular institution, prompting behaviour change in that institution because of fears of negative publicity and/or financial loss, or seeking to raise public awareness with a view to law reform around a particular legal issue. We argue that such strategic litigation positions courts as

115 We note that breach of fiduciary duty has also been raised in the RACF litigation discussed in Part IV(C), but for sake of comparison, this article focuses on the negligence cause of action.

116 For a discussion of the power of strategic litigation in specific contexts, see, eg, Mónica Roa and Barbara Klugman, 'Considering Strategic Litigation as an Advocacy Tool: A Case Study of the Defence of Reproductive Rights in Colombia’ (2014) 22(44) Reproductive Health Matters 31.

117 Michael Ramsden and Kris Gledhill, 'Defining Strategic Litigation' (2019) 38(4) Civil Justice Quarterly 407,411 . 
key sites for considering, contesting and determining what institutional responsibility looks like and what the specific standard of care owed to people in sites of confinement entails. In the context of COVID-19 litigation, this is necessarily limited to the structure and doctrines of tort law, including its methods for determining 'reasonable' standard of care and any resulting remedies. However, as we will demonstrate, while this often embeds a particular reformist tendency into the resulting legal outcomes, it also opens up possibilities for questioning structural and social logics of sites of confinement themselves as well as challenging the logic of disposability identified in Part III above.

The existence of particular duties of care towards people in IDCs and RACFs is well-established in Australian law. Courts have found that RACFs have an obligation to ensure that they have 'in place a regime of care reasonably expected of a nursing home of that size and type', including staff who exercise 'the degree of care and skill expected of an ordinarily careful and competent carer of elderly frail people'. ${ }^{118}$ Similarly, courts have recognised that the Commonwealth's duty of care to people in IDCs extends to having a reasonable regard to their health and safety while in detention, including providing appropriate healthcare such as specialised psychological and psychiatric services. ${ }^{119}$ This means that, in both sites, the existence of a legal duty of care is not in dispute. Rather, it is the scope of the particular duty of care (rather than its existence per se) that remains open to dispute or litigation, including a determination about the required standard of conduct and whether it has been breached in specific factual circumstances. Moreover, the foundational issue of whether certain populations should be differentially subjected to confinement sits outside of duty of care considerations: in law, the duty applies only once an individual is within the particular site of confinement or under a Minister's or institution's care.

Despite these recognised legal duties, in practice many harms arising from IDCs and RACFs remain legally unaddressed. Research in the context of RACFs, for example, suggests a limited number of negligence matters in Australia being brought by residents or their families relative to the actual incidence of abuse and neglect in RACFs. ${ }^{120}$ Those who are older and/or disabled also face more general barriers to accessing justice, ${ }^{121}$ which can be compounded when living in

118 Chan v Barter \& Barter [2003] SADC 5, [91] (Smith J).

119 See Secretary, Department of Immigration and Multicultural and Indigenous Affairs v Mastipour (2004) 259 FCR 576. Although Behrooz v Secretary, Department of Immigration and Multicultural and Indigenous Affairs (2004) 219 CLR 486 was a case of alleged unlawful detention, the Court nonetheless recognised that the statutory regime of immigration detention does not deprive people in immigration detention of the 'right to sue in tort or to pursue other causes of action generally available to citizens and others in the community': at 560 [219] (Callinan J); and that 'those who manage a detention centre ... may be liable in tort' if they do not comply with their duty of care: at 499 [21] (Gleeson CJ). In addition, McHugh, Gummow and Heydon JJ noted that the Migration Act 1958 (Cth) confers 'no immunity from liability in negligence for breach of a duty of care nor from the application of the general criminal law': at 507 [52].

120 Michael Barnett and Robert Hayes, 'Not Seen and Not Heard: Protecting Elder Human Rights in Aged Care' (2010) 14 University of Western Sydney Law Review 45, 72-3.

121 See, eg, House of Representatives Standing Committee on Legal and Constitutional Affairs, Parliament of Australia, Older People and the Law (Report, September 2007) $<$ https://www.aph.gov.au/Parliamentary_Business/Committees/House_of_Representatives_Committees? 
institutional environments like RACFs. ${ }^{122}$ Similarly, the vast majority of people who are in, or have been in, IDCs do not initiate actions based in tort law, despite extensive evidence of the harmful nature of detention, particularly when subjected to long-term, indefinite detention. ${ }^{123}$ Where negligence claims for IDC-related injuries have been initiated, they largely tend to be settled out of court. ${ }^{124}$ While this may avoid prolonged court proceedings and legal costs, it reduces the possibility of institutional transparency or public attention for such cases, and the setting of precedent. ${ }^{125}$

Despite this, courts remain a central site for articulating, contesting and advancing claims for those in IDCs and RACFs, including determining notions of 'reasonable' conduct on the part of the authorities that have control over their lives, as we have seen in challenges to the treatment of people in 'offshore' detention. ${ }^{126}$ In relation to 'onshore' IDCs, while courts have ordered injunctive relief that has compelled the Commonwealth to take particular actions, the remedy sought is often limited by the particular statutory regime. ${ }^{127}$ For example, in 2011 , a Federal

url=/laca/olderpeople/report.htm>; Australian Law Reform Commission, Elder Abuse: A National Legal Response (Final Report No 131, May 2017) <https:/www.alrc.gov.au/publication/elder-abuse-a-nationallegal-response-alrc-report-131/>; Sarah Ellison et al, 'Access to Justice and Legal Needs: The Legal Needs of Older People in NSW' (Report, Law and Justice Foundation of New South Wales, December 2004); Abigail Gray, Suzie Forell and Sophie Clarke, 'Cognitive Impairment, Legal Need and Access to Justice' (Paper No 10, Law and Justice Foundation of New South Wales, March 2009).

122 See also the context of complaints procedures and criminal justice processes, Joseph Ibrahim and David Ranson, 'Neglect in Aged Care: A Role for the Justice System?' (2019) 27(2) Journal of Law and Medicine 254, 258; 'Department of Finance: Compensation for Immigration Detainees', Australian Lawyers Alliance (Web Page, 5 July 2017)

$<$ https://www.lawyersalliance.com.au/ourwork/2017/department-of-finance----compensation-forimmigration-detainees $>$.

123 On the pervasiveness of psychiatric harms experienced in people in IDCs, especially by long-term detainees, and their potential claims in negligence, see Claire O'Connor, 'Personal Injury Claims for Immigration Detainees' (2013) 116 Precedent 24, 29.

124 Helen Davidson, 'Wilson Security Settles out of Court with Refugee Who Alleges Nauru Guard Raped Her', The Guardian (online, 25 November 2019) < https://www.theguardian.com/australianews/2019/nov/25/wilson-security-settles-out-of-court-with-refugee-who-alleges-nauru-guard-rapedher>.

125 For example, between 1999 and 2012, the Australian government paid out over AUD5 million in compensation to former detainees who suffered physical injuries or psychological damage while in IDCs. This sum does not include compensation claims for unlawful detention (which amounted to AUD18 million for the same period): Department of Finance and Deregulation (Cth), 'Compensation Claims Made by Immigration Detainees between 1999 and 2011' (Finance FOI Release No 11/75, 8 November 2011). It is difficult to ascertain the precise details of these cases as many successful compensation cases have been settled out of court. More recently, in the 2016-17 financial year, the Australian government paid around $\$ 60,000$ in personal injury claim management arising out of immigration detention cases: see Department of Finance (Cth), 'Department of Immigration Act of Grace Payments for 2016-17 Financial Year' (Finance FOI Release No 17/83, 11 July 2017). In contrast, the dispersed nature of RACF providers makes it difficult to know exactly how many negligence claims have been brought against the industry in Australia as a whole (despite the extent of reported incidents of assault in RACFs recorded in the Minister's annual reports, as discussed in Part II).

126 See Anna Talbot and George Newhouse, 'Strategic Litigation, Offshore Detention and the Medevac Bill' (2019) 13 Court of Conscience 85; Gabrielle Holly, 'Challenges to Australia's Offshore Detention Regime and the Limits of Strategic Tort Litigation' (2020) 21(3) German Law Review 549; Dehm (n 32).

127 See also earlier case of $S v$ Secretary, Department of Immigration and Multicultural and Indigenous Affairs (2005) 143 FCR 217, 271 [262], 273 [169] where Finn J held that he would have granted 
Court judge ordered the Commonwealth to 'use its best endeavours' to place an unaccompanied child (who had been found to be a refugee, yet remained in immigration detention after being issued an adverse Australian Security Intelligence Organisation assessment) in 'a form of immigration detention in Melbourne in the State of Victoria which provides a supportive residential or family-based environment' ${ }^{128}$ Yet, in the subsequent case of MZYYR the Federal Court dismissed an application for interlocutory injunction to compel the Commonwealth to place a Kurdish man in an alternate form of detention to the Melbourne Immigration Transit Accommodation ('MITA') which would provide him with 'adequate ... treatment to meet his mental health needs'. This decision was reasoned on the basis that the man appeared 'more settled' at MITA than under previous detention arrangements and the judge was 'reluctant to change the status quo in the absence of an identified facility with appropriate and available medical treatment'. ${ }^{129}$ Despite this, Gordon J was prepared to order the Commonwealth to provide 'appropriate medical services' to the man at MITA in order to restrain a continuing tort, stating in obiter remarks that ' $[\mathrm{t}] \mathrm{he}$ Commonwealth is in a position of control. Detainees cannot reasonably be expected to safeguard themselves from danger, especially detainees with mental health needs which are known to the Commonwealth'. ${ }^{130}$

As a result, while the courts provided certain forms of injunctive relief around the provision of healthcare in IDCs, these have been quite limited in practice and mindful of the statutory scheme of mandatory detention. ${ }^{131}$ In contrast, injunctive relief has not been routinely used to date to stop continuing or apprehended breaches of duty of care in RACFs. In what follows, we outline and evaluate key litigation across both RACFs and IDCs that has been initiated in the context of and in response to the pandemic.

injunctive relief ordering the Commonwealth to transfer two asylum seekers from immigration detention to an Adelaide mental health facility had the Commonwealth not already transferred the men there. See discussion in Bernadette McSherry and Azadeh Dastyari, 'Providing Mental Health Services and Psychiatric Care to Immigration Detainees: What Tort Law Requires' (2007) 14(2) Psychiatry,

Psychology and Law 260.

128 A Child (by his next friend, Arthur) v Secretary, Department of Immigration and Citizenship [No 2] [2011] FCA 1519 (Mansfield J).

129 MZYYR v Secretary, Department of Immigration and Citizenship (2012) 292 ALR 659, 660-1 [4], 667 [31], 671 [53] (Gordon J). Nonetheless, the case set an important principle that the Commonwealth has a duty of care to people in immigration detention to 'provide the person with the level of medical care which is reasonably designed to meet their health care needs, including psychiatric care': at 663 [20]. Ibid 671-2 [55]-[56] (Gordon J).

131 See also Secretary, Department of Immigration and Multicultural and Indigenous Affairs v Mastipour (2004) 259 FCR 576, 594 [141], 595 [144] (The Court) where the Full Federal Court, on appeal, issued an interlocutory order restraining the Commonwealth from detaining an Iranian man at Baxter IDC and from removing him to Port Hedland IDC (revising an earlier FCA order that had instructed the Commonwealth to detain the man at either Villawood or Maribyrnong IDCs on the basis that such an order was 'inappropriate' and did not 'give the Secretary the flexibility to move Mr Mastipour if that is required'): at 594 [141]. 


\section{B Immigration Detention Litigation during COVID-19}

Since the start of the pandemic, there have been two noteworthy negligence cases brought by human rights advocates to challenge the government's refusal to release people from IDCs as a COVID-19 measure. One case, Plaintiff M37/2020 $v$ Commonwealth ('Plaintiff M37/2020'), was initiated in late April 2020 by the Human Rights Law Centre on behalf of a man detained at a Brisbane IDC, but subsequently discontinued in mid-May due to the lack of COVID-19 community transmission in Queensland at the time. ${ }^{132}$ The other, BNL20 v Minister for Home Affairs ('BNL20'), was initiated shortly prior to Plaintiff M37/2020 on behalf of a man detained at MITA but was heard subsequently.

In Plaintiff M37/2020, the plaintiff was a man with a series of pre-existing medical conditions that made him particularly at risk of severe illness or death if he contracted COVID-19. ${ }^{133} \mathrm{He}$ had been found to be a refugee under Australia's offshore detention regime and transferred to the Australian mainland for medical treatment from Manus Island in early 2019. The case was brought against both the Commonwealth and the Minister of Home Affairs, with the main argument being that both respondents owed a duty to take reasonable care for the 'safety and to prevent foreseeable injury' to people detained in IDCs. ${ }^{134}$ While the existence of this duty was not in contention, what was disputed was the particular scope of the respondents' duty and what specific steps the respondents were required to take in the context of COVID-19 to care for people detained in IDCs. The plaintiff argued that, given the respondents largely controlled the conditions in IDCs, such a duty of care obliged them to take reasonable steps to prevent the plaintiff from contracting COVID-19 and to enable the plaintiff to heed government guidelines on protective measures against COVID-19. ${ }^{135}$ Specifically, the plaintiff submitted that the particularities of IDCs meant that it was 'highly likely' that COVID-19 could spread quickly if it entered the Brisbane facility. ${ }^{136}$ Accordingly, the nature of IDCs meant that the plaintiff was unable to take reasonable steps to protect himself, nor was he able to adhere to government social distancing directives. Additionally, the plaintiff argued that placing him in solitary confinement would

132 Plaintiff M37/2020, 'Statement of Claim', Submission in Plaintiff M37/2020v Commonwealth, VID272/2020, 1 May 2020. The case was initially filed in the High Court and was remitted to the Federal Court for determination at the request of the plaintiff.

133 The man's pre-existing medical conditions included asthma, a heart condition and diabetes: 'Legal Challenge Filed to Protect Refugee at COVID-19 Risk in Immigration Detention', Human Rights Law Centre (Media Release, 22 April 2020) <https://www.hrlc.org.au/news/2020/4/21/legal-challengerefugee-at-covid-19-risk>.

134 Plaintiff M37/2020, 'Statement of Claim', Submission in Plaintiff M37/2020v Commonwealth, VID272/2020, 1 May 2020, [23].

135 The case also included an additional argument in relation to the Commonwealth's obligations under occupier's liability duty.

136 These specific conditions included the 'difficulty or impossibility of avoiding overcrowding' within the facility (in particular in meal areas); the frequent movement and rotation of staff within the facility; the delay in accessing medical services; the inconsistent use by staff of PPE within the IDC; and the use of shared bedroom, bathroom and other facilities (including the inability 'to control or restrict who enters his bedroom, bathroom and common area that he uses'): Plaintiff M37/2020, 'Statement of Claim', Submission in Plaintiff M37/2020 v Commonwealth, VID272/2020, 1 May 2020, [15]-[16]. 
not only fail to reduce the risk of contracting COVID-19, it would cause him serious harm. ${ }^{137}$

The plaintiff's advocates framed the litigation as a regrettable but necessary measure to compel the respondents to heed their own COVID-19 public health guidelines as well as the advice of medical experts. ${ }^{138}$ The main legal outcome sought was an order restraining the Commonwealth from continuing to breach its duty of care to the plaintiff by detaining him in circumstances where he is unable to adhere to the government COVID-19 advice nor able to practice proper hygiene and social distancing. Specifically, the plaintiff emphasised that the relief sought was confined to ensuring the Commonwealth would discharge its duty of care and would extend "no further than necessary to ameliorate the present and continuing harm' to the plaintiff. As a result, the plaintiff contended that such an order could be 'effected by the respondents consistently with the statutory obligation to detain which obtains under the Act'. ${ }^{139}$ This meant that, while the case was framed in a way that was cognisant of the courts' limits in relation to ordering a release from IDCs, the implication of such an order was to prompt release into community detention.

In defence, the respondents argued that the scope of their duty needed to be consistent with the mandatory detention scheme under the Migration Act, and that it was legally unreasonable for them to adopt the additional precautionary measure of release into community detention given the low probability that the plaintiff would suffer harm if such precautions were not taken; the high burden on the respondents involved with taking such precautions; the 'social utility' of immigration detention; ${ }^{140}$ and the limited 'financial and other resources' available to the respondents for the purpose of immigration detention. ${ }^{141}$ It is here that the logic of disposability appears to structure the government's response to people in IDCs: 'protective' action was framed as being too burdensome and expensive, even though, for instance, the economic cost of detaining a person in an IDC is far

137 Ibid 11 [22].

138 For example, David Manne (Refugee Legal) stated that: 'The Government has the opportunity to heed the expert medical advice by ensuring people are released into safe accommodation. If the Government does not act, there is no option but to resort to the courts to ensure that these women and men receive the same protection that everyone deserves in this pandemic. Protecting these vulnerable people protects us all': 'Legal Challenge Filed to Protect Refugee at COVID-19 Risk in Immigration Detention', Human Rights Law Centre (Media Release, 22 April 2020) <https:/www.hrlc.org.au/news/2020/4/21/legal-challengerefugee-at-covid-19-risk>.

139 Plaintiff M37/2020 'Submissions', Submission in Plaintiff M37/2020 v Commonwealth, VID 272/2020, 24 April 2020, [14].

140 Judicial consideration of the 'social utility' of a risk-creating activity is a well-established principle within the negligence calculus to determine generally the standard of care of a reasonable person in the defendant's position. See, eg, Civil Liability Act 2003 (Qld) s 9(2)(d) in the context of Plaintiff M37/2020 $v$ Commonwealth. For select judicial discussions of the concept of 'social utility', see Wilson v Nilepac Pty Ltd [2011] NSWCA 63, [126]-[130] (Tobias JA); Southern Properties (WA) Pty Ltd v Executive Director of the Department of Conservation and Land Management (2012) 42 WAR 287, 336 (Pullin JA); Roo Roofing Pty Ltd v Commonwealth [2019] VSC 331 [426], [782] (Dixon J); Carvalho v Town (2020) 91 MVR 155, 173 [102] (Mossop J).

141 Commonwealth of Australia, 'Defence', Submission in Plaintiff M37/2020v Commonwealth, VID 272/2020, 8 May 2020, [25]. 
more costly than allowing a person to live in the community. ${ }^{142}$ Ultimately though, by the time that the case was heard in early May 2020, COVID-19 community transmission rates in Queensland had dropped so low that the claim's prospect of success had lessened and the parties agreed to discontinue the case, subject to an earlier interim order remaining on foot until mid-June $2020 .{ }^{143}$

The other case, in contrast, has been marginally more successful in terms of legal outcomes, but in practice has not fundamentally challenged the punitive logic or practice of immigration detention. Like the discontinued Plaintiff M37/2020, $B N L 20$ rested upon a duty of care argument that also asserts that the Minister must 'take reasonable steps to protect' the applicant from foreseeable COVID-19 related risks of harm while in IDCs. ${ }^{144}$ The applicant in BNL20 was a 68 -year-old refugee who had been detained in MITA since late 2019 and was also diabetic. The applicant had arrived in Australia 10 years earlier, and was living with his family in the community until his visa was cancelled on allegations of him having provided financial assistance to people smuggling operations nearly 15 years prior. The applicant's sex, age and medical condition placed him within recognised groups of people who were at a 'substantially increased risk of death' if they contracted COVID-19. ${ }^{145}$

Yet unlike Plaintiff M37/2020, the applicant in BNL20 was able to obtain a court order restraining the Minister from detaining him in MITA from early August onwards. ${ }^{146}$ The application for interlocutory relief in BNL20 was also based on the fact of COVID-19 community transmission, including that COVID19 was 'spreading rapidly within the Victorian community'. ${ }^{147}$ What made $B N L 20$ distinct from Plaintiff M37/2020 was that the application for the order was heard and granted against a background of rising infection rates in Victoria in early August, enabling the applicant to rely upon expert evidence that group custodial settings like MITA were unsafe for people at high risk of COVID-19. ${ }^{148}$ The court

142 Asylum Seeker Resource Centre, 'At What Cost? The Human and Economic Cost of Australia's Offshore Detention Policies' (Report, 2019). See also Kaldor Centre, 'The Cost of Australia's Asylum and Refugee Policies: A Source Guide' (Factsheet, 5 May 2020).

143 'Notice of Discontinuance', Plaintiff M37/2020 v Commonwealth, VID 272/2020, 19 May 2020. The number of recorded COVID-19 cases in Queensland was 1,033 cases on 1 May 2020 and 1,054 cases on 15 May 2020: Department of Health (Qld), 'Queensland Novel Coronavirus (COVID-19) Update' (Media Release, 1 May 2020) <https://www.health.qld.gov.au/news-events/doh-mediareleases/releases/queensland-novel-coronavirus-covid-19-update-2020-05-01>; Department of Health (Q1d), 'Queensland Novel Coronavirus (COVID-19) Update' (Media Release, 15 May 2020) $<$ https:/www.health.qld.gov.au/news-events/doh-media-releases/releases/queensland-novel-coronaviruscovid-19-update41>.

144 BNL20, 'Statement of Claim', Submission in BNL20 v Minister for Home Affairs, VID239/2020, 8 April 2020, [8].

145 Ibid [19].

146 BNL20 v Minister for Home Affairs [2020] FCA 1180 (Murphy J). The Federal Court also ordered the Minister to inform the applicant's lawyers about the steps or proposed steps that they took or would take to comply with the order.

147 BNL20, 'Statement of Claim', Submission in BNL20v Minister for Home Affairs, VID239/2020, 8 April 2020, [18].

148 'Federal Court Orders Minister to Stop Detaining Elderly Man at Melbourne Detention Centre Due to COVID-19 Risk to His Life', Asylum Seeker Resource Centre (Blog Post, 10 August 2020) 
order heralded a significant victory compelling the Commonwealth to act to protect people in IDCs from risks of COVID-19. It indicated a judicial willingness to assess the potential harms posed by immigration detention to particular individuals as well as to scrutinise the specific conditions of a person's detention, and to issue judicial orders to prevent a tort from occurring. It also attracted considerable public attention to the failures and hypocrisy of the federal government's COVID-19 response. ${ }^{149}$ As the applicant's solicitor, Sanmati Verma, stated on the day of the court granting interlocutory relief, the court's decision 'makes it clear the Commonwealth is unable to ensure the safety of vulnerable people such as our client in detention'. ${ }^{150}$

Yet, while the granting of interlocutory relief in BNL20 was certainly significant, the government's subsequent actions demonstrate their refusal to concede any authority to the courts to compel releases from immigration detention. Rather than releasing the applicant into community detention, where he would have been able to return to live with his family, the Minister opted on transferring the plaintiff to a different IDC in Western Australia, Yongah Hill IDC, over 3,000 $\mathrm{km}$ away from the applicant's family in Melbourne. A subsequent application to the Federal Court to prevent his removal failed. ${ }^{151}$ Given that there were very low COVID-19 infections in Western Australia, the key legal argument open to the applicant to prevent the transfer was that transferring the applicant was too risky, exposing him to the possibility of becoming infected with COVID-19 during transfer. In response, the respondents' counsel argued that it was theoretically possible for the respondents to comply with the court order by transporting the refugee in solitary confinement by truck to Western Australia or by 'build[ing] an entire new detention centre for one person to stay in' ${ }^{152}$ The respondents' counsel also confirmed in court that the Minister had no intention of releasing the applicant into community detention, even though the Minister had not been personally briefed on the applicant's case. ${ }^{153}$ Such legal outcomes demonstrate the limits of strategic litigation in the face of a statutory regime mandating immigration

$<$ https://www.asrc.org.au/2020/08/10/federal-court-orders-minister-to-stop-detaining-elderly-man-atmelbourne-detention-centre-due-to-covid-19-risk-to-his-life/>.

149 See Ferdinand, Loughnan and Murray (n 92).

150 Australian Associated Press, 'Govt Detention of Man "Must Cease": Court', Canberra Times (online 11 August 2020) <https://www.canberratimes.com.au/story/6873044/govt-detention-of-man-must-ceasecourt/?cs=14264>.

151 Australian Associated Press, 'Court Delays Bid to Move Man from Immigration Detention in Melbourne to WA', The Guardian (online, 12 August 2020) <https://www.theguardian.com/australianews/2020/aug/12/court-delays-bid-to-move-man-from-immigration-detention-in-melbourne-to-wa>.

152 'Melbourne Immigration Detainee to Be Forcibly Flown to WA after Losing Coronavirus Court Battle', SBS News (online, 19 August 2020) <https://www.sbs.com.au/news/melbourne-immigration-detainee-tobe-forcibly-flown-to-wa-after-losing-coronavirus-court-battle $>$.

153 As the applicant's lawyer subsequently stated: 'It beggars belief that the government would fly a sick, elderly man thousands of kilometres from his family home in Melbourne. The Commonwealth's response to the health crisis in the detention network has been haphazard and dangerous, for detainees, staff and the broader community': 'Federal Government Set to Transfer Sick, Elderly Melbourne Man away from Family to Perth Immigration Detention following COVID-19 Court Ruling', Human Rights Law Centre (Media Release, 19 August 2020) <https://www.hrlc.org.au/news/2020/8/19/govt-to-transfer-sickelderly-man-away-from-family-to-perth-immigration-detention>. 
detention, exacerbated through a governmental callousness towards people detained in IDCs. Although BNL20 remains on foot at the time of writing, the Minister's response to the interlocutory order has affirmed and intensified the logic of exclusion and incarceration vis-à-vis refugees and other criminalised noncitizens.

There are three significant aspects of these cases that offer potential possibilities for and limitations to advancing legal accountability. The first aspect is the insistence on situating people in IDCs within a general public health response - thus demanding equality of treatment between those in detention and those in the general community. A key argument in the litigation rested upon the capacity of those in IDCs to be able to follow Commonwealth government-issued COVID-19 public health advice around practicing personal hygiene and social distancing. Both statements of claim argued that Commonwealth government-issued COVID19 public health advice applied to people in IDCs, drawing on medical evidence to do so. Yet, the respondents disputed this claim, instead opting to emphasise a distinction between people in IDCs and the public in general. For example, in their Plaintiff M37/2020 defence, the respondents argued that Commonwealth advice recommending good personal hygiene practices and practising social distancing were 'particularised communications ... directed at the public generally and not directed specifically at persons detained in immigration detention centres'. ${ }^{154}$ This articulates a broader structural tendency both in law and in certain public health responses to treat asylum-seeker and refugee populations as 'separate, distant and disconnected from the host communities' in which they live. ${ }^{155}$ Nonetheless, the litigation opened the possibility to contest such practices of exclusion and segregation, mobilising public discourse to insist on characterising people in IDCs as members of a larger 'public' that ought to be equally protected as part of the COVID-19 public health response. This broadens ideas of 'public' inclusion, and refuses the legal categories which enforce a distinction between people as either citizens or non-citizens. ${ }^{156}$

Second, the cases significantly sought to reconfigure legal relations of care, responsibility and accountability between the Australian government and people incarcerated in IDCs. In focusing their legal claims primarily on the Commonwealth, both cases did not specifically include the private company running the IDC, Serco, as a formal respondent. Nonetheless, the plaintiff's case was formulated so as to also cover their conduct as agents of the Commonwealth under the direction and control of both respondents. In contrast, the respondents' defence stressed Serco as an independent entity contracted to deliver certain

154 Commonwealth of Australia, 'Defence', Submission in Plaintiff M37/2020v Commonwealth, VID 272/2020, 8 May 2020, [12].

155 Natalie J Grove and Anthony B Zwi, 'Our Health and Theirs: Forced Migration, Othering, and Public Health' (2006) 62(8) Social Science and Medicine 1931, 1931.

156 Instead, it emphasises an idea of the 'public' as the actually-existing population within a state's territory. Etymologically, the concept of 'public' stems from an intertwining of the terms poplicus (meaning 'of the people') and pubes (meaning 'adult'). While each of these two terms derive their meaning through their respective exclusions (ie the 'non-people' and 'non-adults'), it is telling that the use of the 'people' is different to the people as 'demos' as the foundational concept of democratic theory (which is premised on a logic of inclusion/exclusion): see Chantal Mouffe, The Democratic Paradox (Verso, 2000). 
services, which is merely 'subject to such direction and control by the Commonwealth as is lawfully permitted under the terms of their engagement ${ }^{157}$ Under the Detention Services Contract, Serco already formally acknowledges that it has a duty of care towards detainees that sits alongside and is not modified by any duty of care owed by the Department. ${ }^{158}$ While the initial interim order in Plaintiff M37/2020, for example, did order that respondents ensure that the applicant was provided with PPE and accommodated in a single room, ${ }^{159}$ it did not explicitly name Serco as an entity subject to this formal obligation and did not compel Serco to take more general preventative actions including properly screening its employees to avoid them bringing COVID-19 infections into IDCs or providing PPE to all staff, contractors and detainees. Accordingly, such litigation can lead to a disjuncture between how legal relations of responsibility are framed and enforced, and the practicality of everyday IDC operations including how people in IDCs experience their incarceration and who is exercising control over their lives.

Third, while the appeal to medical expertise allowed for framing and substantiating the foreseeable risk of harm to the plaintiff, both cases relied upon a factual background of increasing or high level of COVID-19 community infections or transmission. Indeed, the Plaintiff M37/2020 statement of claim lists 'existing community transmission' as one of several factors that make it 'extremely likely' that COVID-19 infections will enter the Brisbane immigration detention facility. ${ }^{160}$ Likewise, the applicant's arguments in BNL20 rested upon that COVID-19 'will enter MITA once there is widespread community transmission of SARS-CoV-2' ${ }^{161}$ Such arguments necessarily 'exceptionalise' the particular standard of care required by the Commonwealth/Minister as confined to times of health emergencies like pandemics. In the case of Plaintiff M37/2020, this meant that the case was discontinued once Queensland infections had significantly reduced, while in the $B N L 20$ case, this has meant that the Minister was able to deem Western Australia a viable alternative immigration detention location. Ironically, it suggests the effectiveness of such litigation strategies is more likely should there be high COVID-19 community transmission across all Australia.

157 Commonwealth of Australia, 'Defence', Submission in Plaintiff M37/2020 v Commonwealth, VID272/2020, 8 May 2020, [4].

158 Department of Immigration and Border Protection (Cth) and Serco Australia Pty Ltd, 'Detention Services Contract' (n 32) s 13 .

159 Order of Kenny J in Plaintiff M37/2020 v Commonwealth (Federal Court of Australia, VID272/2020, 24 April 2020).

160 Other named factors included: 'the known vulnerability of custodial settings, in particular where there is no vaccine; staff moving between the community and detention facility; staff and inmates sharing background and relations with world locations of high prevalence ... and that viral shedding can occur prior to the onset of symptoms, such that excluding symptomatic people from entering will not remove the risk of an infected person entering': Plaintiff M37/2020, 'Statement of Claim', Submission in Plaintiff M37/2020 v Commonwealth, VID272/2020, 1 May 2020, [14].

161 BNL20, 'Statement of Claim', Submission in BNL20 v Minister for Home Affairs, VID239/2020, 8 April $2020,[44]$. 


\section{Aged Care Litigation during COVID-19}

In the RACF context, emerging litigation is taking the form of class actions principally for the psychological impacts on family members of the death or injury of residents. Again, to date, there are two noteworthy cases on foot against two RACF providers with aged care facilities ('ACFs') located in Victoria (Epping Gardens ACF) and NSW (St Basil's ACF).

In mid-August 2020, some family members of Epping Gardens ACF residents commenced a class action against Heritage Care Pty Ltd through Carbone Lawyers. ${ }^{162}$ The group on whose behalf the class action was commenced is defined in the writ as consisting of four categories: (a) persons who had a close proximate relationship to a resident who was killed, injured or put in danger by the acts or omissions of RACF providers during the pandemic (eg close family members); (b) residents who sustained injury, mental or nervous shock, loss and damage and/or were put in danger by acts or omissions of RACF providers during the pandemic; (c) legal representatives of a deceased resident who was killed, injured or put in danger by the acts or omissions of the defendant during the pandemic; and (d) all employees who worked at Epping Gardens during the pandemic and sustained physical injury, mental or nervous shock in connection with that employment and/or were put in danger by acts or omissions of the defendant. ${ }^{163}$

The representative member in the class action is Sebastian Agnello. His 90year-old mother was a resident at Epping Gardens ACF who died from contracting COVID-19. The writ identifies 26 grounds for breach of duty of care, primarily focused on infection control and compliance, but also extending to concealing information from the plaintiff about the deceased and concealing information from the plaintiff and government authorities concerning the broader COVID-19 risks. ${ }^{164}$ The Statement of Claim sought damages and punitive damages for negligence giving rise to nervous shock. ${ }^{165}$ The claim for punitive damages is on the basis of the particularly serious nature of conduct giving rise to breach. ${ }^{166}$

Within a week of filing the Epping Gardens writ, a subsequent class action was commenced by Carbone Lawyers in relation to St Basil's ACF. ${ }^{167}$ The

162 Cameron Houston et al, 'Aged Care Homes Face Threat of Legal Action Amid Negligence Claims', The Age (online, 6 August 2020) $<$ https://www.theage.com.au/national/victoria/aged-care-homes-face-threatof-legal-action-amid-negligence-claims-20200806-p55j7i.html>. See Sebastian Agnello, 'Writ',

Submission in Agnello v Heritage Care Pty Ltd, S ECI 2020 03282, 14 August 2020.

163 See, eg, Sebastian Agnello, 'Statement of Claim', Submission in Agnello v Heritage Care Pty Ltd, S ECI 2020 03282, 14 August 2020, 3-4 [3].

164 Ibid 6-8 [18].

165 Ibid 10 .

166 The Statement of Claim states that 'at all times material the defendant knew, that by reason of its conduct, it was putting the deceased at risk of death or serious injury and that nevertheless in wanton and contumelious disregard of the deceased and her health the defendant chose to knowingly continue to provide aged care services and accommodation in breach of Federal and State Government legislation, regulations, guidelines and directions. Further, in all the circumstances the defendant either knew or ought to have known that in doing so there was a reasonable likelihood the deceased would die or suffer serious injury. As a consequence of the above the plaintiff and each of the group members claim punitive damages against the defendant': ibid 9-10 [24].

167 Efstathia Fotiadis, 'Writ', Submission in Fotiadis $v$ St Basil's Homes for the Aged in Victoria, S ECI 2020 03339, 20 August 2020. See also Josh Taylor, 'St Basil's Faces Class Action Suit for Allegedly 
representative plaintiff is Efstathia ('Effie') Fotiadis. Her father, Dimitrios Fotiadis, was a 79-year-old resident of the RACF who died of COVID-19. The writ is similar in terms to the Epping Gardens class action: similar categories in the class action group, bases for duty of care and breach of duty of care, and similar focus on damages for mental harm. Shine Lawyers has also announced that they are investigating two possible class action in relation to COVID-19 deaths at Cumberland Manor ACF and Newmarch House ACF. ${ }^{168}$ In the media release regarding Newmarch House, Shine Lawyers stated that they will 'allege the aged care provider was negligent in its handling of the health crisis and breached its duty of care to residents', emphasising the failure to immediately transport infected residents to hospital, the lack of information provided to family about the outbreak, and the absence of staff who were qualified or supported to make critical decisions: 'The reality is lives would have been saved if Newmarch House had the right protocols and medical care procedures in place and adhered to them from the start'. ${ }^{169}$

Beyond these class actions, law firms are predicting broader litigation against RACFs. Indeed, comments attributed to the law firm Norton Rose Fulbright reportedly stated that there is a "serious risk" of industry-wide class actions against Australia's aged care sector ... which - if brought - would place that sector under "enormous financial strain" and give rise to numerous headaches for governments, the broader healthcare landscape as well as the general community'. ${ }^{170}$ Jack Pembroke-Birss, partner at Norton Rose Fulbright, has suggested that legal action could include negligence claims similar to the two class actions discussed above, and 'claims for false imprisonment for those residents who were wrongly told they could not leave the facility under public health orders that said nothing of the sort' ${ }^{171}$ While these class actions are in a much earlier stage than the immigration litigation discussed above, in what follows, we identify three significant sets of possibilities and potential limitations with this emerging approach. Many of the limitations arise from inherent legal or strategic dimensions

Breaching Duty of Care amid Covid Crisis', The Guardian (online, 20 August 2020)

$\leq$ https://www.theguardian.com/australia-news/2020/aug/20/st-basils-faces-class-action-suit-for-allegedlybreaching-duty-of-care-amid-covid-crisis>.

168 Shine Lawyers, 'Shine Lawyers Investigates Class Action over Deaths at Newmarch House' (Media Release, 1 July 2020) <https://www.shine.com.au/media-centre/media-releases/shine-lawyersinvestigates-class-action-over-deaths-at-newmarch-house >; Shine Lawyers, 'Class Action Brewing over Deadly COVID-19 Outbreak' (Media Release, 8 November 2020) <https:/www.shine.com.au/mediacentre/media-releases/class-action-brewing-over-deadly-covid-19-outbreak>.

169 Shine Lawyers, 'Shine Lawyers Investigates Class Action Over Deaths at Newmarch House' (Media Release, 1 July 2020) <https://www.shine.com.au/media-centre/media-releases/shine-lawyersinvestigates-class-action-over-deaths-at-newmarch-house $>$.

170 Jerome Doraisamy, 'Aged Care Class Actions “Imminent”, Says NRF', Lawyers Weekly (online, 12 August 2020) <https://www.lawyersweekly.com.au/biglaw/29172-aged-care-class-actions-imminentsays-nrf $>$. On false imprisonment claims against RACFs more generally, see Judy Allen and Tamara Tulich, "I Want to Go Home Now": Restraint Decisions for Dementia Patients in Western Australia' (2007) 33(2) Law in Context: A Socio-Legal Journal 1; and in the United States context, see Cathrael Kazin, "Nowhere to Go and Chose to Stay": Using the Tort of False Imprisonment to Redress Involuntary Confinement of the Elderly in Nursing Homes and Hospitals' (1989) 137(3) University of Pennsylvania Law Review 903. 
of such litigation, yet in light of the dynamics discussed in Parts II and III above, these limitations are heightened due to the sociopolitical status of people in RACFs.

A first set of possibilities and potential limitations relates to the structure of class actions. Class actions (or 'group proceeding ${ }^{172}$ ) have many benefits in terms of access to justice, and time and cost efficiency for claimants. As noted by Murphy and Cameron, there has been judicial acknowledgement that 'the class action mechanism makes it possible to pursue legitimate claims arising from mass wrongs that would not be addressed if individuals were left to seek a remedy on their own' ${ }^{173}$ Bringing together residents with family members and employees in the same claim provides collective capacity to bring legal action which might otherwise be difficult for individual residents due to access to justice issues. Yet, the class action approach might marginalise public recognition of legal accountability owed specifically to residents. In both the COVID-19 cases so far, the representative plaintiff ${ }^{174}$ has been a family member of a deceased resident, not a surviving resident. Of course, there are many practical and strategic reasons behind selection of the representative plaintiff that might explain this choice (eg, managing the litigation on behalf of the group on a day-to-day basis). In legal terms, the 'representative party's claim need not be typical of the group members' claims' nor do they need to have a similar relationship to the defendant. ${ }^{175}$ It has also been argued that there is no 'clear theoretical or doctrinal underpinning of the representative party's role' vis-à-vis group members. ${ }^{176}$ However, the fact that the representative plaintiff is the 'public face' of the litigation focuses our attention on the situation and suffering of family members rather than residents. ${ }^{177} \mathrm{~A}$ family member representative plaintiff might have a synecdochical effect of contributing to the public perception that the class action is purely for family members (and this is certainly the case in the initial media reporting of the class action) and/or filters the injustices and harms of the defendants' negligence through the legally documented experiences of family members. Hence, in the RACFs context the class action might have reduced utility as a vehicle for public recognition of the harms to residents themselves and their status as agential subjects. This is concerning, given the loss of autonomy already characterising confinement and the use of restrictive practices in RACFs, exacerbated during COVID-19.

A further concern is that the damages sought tend to focus on individual harms and injury undergone rather than on the structural conditions which lead to that harm, such as confinement, social isolation and neglect. For instance, the requirement in negligence law that mental harm must amount to a psychiatric

172 See Supreme Court Act 1986 (Vic) pt 4A.

173 Bernard Murphy and Camille Cameron, 'Access to Justice and the Evolution of Class Action Litigation in Australia' (2006) 30(2) Melbourne University Law Review 400, 403.

174 Ibid 432-4.

175 Damian Grave, Ken Adams and Jason Betts, Class Actions in Australia (Lawbook Co, 2 $2^{\text {nd }}$ ed, 2012 ) 172.

176 Ibid 176.

177 This is not unlike the absence of children's voices in the Don Dale Royal Commission's reporting: Thalia Anthony, 'Young People's Voices Are All but Invisible in the Don Dale Royal Commission's Interim Report', The Conversation (online, 6 April 2017) <https://theconversation.com/young-peoplesvoices-are-all-but-invisible-in-the-don-dale-royal-commissions-interim-report-75618>. 
illness medicalises social/relational loss, ${ }^{178}$ and only recognises particular manifestations of grief. ${ }^{179}$ Moreover, the legal outcomes sought focus on damages for past/concluded wrongful acts, rather than remedial action which might mitigate against future harms. This means that litigation alone is unlikely to bring about change for the parties or for the residents still in the RACF. The reactive approach in the RACF context, in initiating legal proceedings only following high rates of death at certain RACFs, might speak to perceived or actual lack of options for alternative housing and care for older people within the community, such that it is not feasible to bring actions to get people out of RACFs at the present time. ${ }^{180}$ However, this reflects a failure of public policy and social imagination, sustaining the dynamic of limited 'choice' which drives many into RACFs, as noted in Part II above.

Third, defendants in both class actions are RACF providers, rather than individual employees or the Commonwealth government. There are obvious strategic reasons for this given the RACF provider will presumably have much deeper pockets (by reason of their insurance coverage). ${ }^{181}$ Additionally, pinning accountability to RACF providers sends a message of a structural or cultural failure in RACF service provision and governance, focusing attention on the economic drivers for the negligent conduct. It thus challenges some of the underlying dynamics of the collective harms to older/disabled people and people with disability in RACFs identified in Parts II and III. However, the loss spreading impact of insurance ${ }^{182}$ might impact on the extent to which RACF accountability results in subsequent change in RACF service provision. Any choice to sue the RACF provider, as opposed to the Commonwealth government, can diminish the accountability of that government for its funding and regulation of aged care (unless the aged care providers cross claim or raise the defence of contributory negligence). Such a choice can contribute to government complicity in a broader

178 Iain Field, 'In Mourning of Bereavement Damages' (2014) 22(2) Tort Law Journal 95; Steve Hedley, 'Death and Tort' in Belinda Brooks-Gordon et al (eds), Death Rites and Rights (Hart Publishing, 2007) 241.

179 See, eg, the critical race and feminist critiques of pure mental harm that highlight the trivialising of this category of injury and pathologising of claimants: Martha Chamallas, 'The Architecture of Bias: Deep Structures in Tort Law' (1998) 146(2) University of Pennsylvania Law Review 463; Martha Chamallas and Jennifer B Wriggins, The Measure of Injury: Race, Gender, and Tort Law (New York University Press, 2010) 37-47, 84-117; Prue Vines, Mehera San Roque and Emily Rumble, "Is "Nervous Shock" Still a Feminist Issue? The Duty of Care and Psychiatric Injury in Australia' (2020) 18(1) Tort Law Review 9. This speaks to a broader limitation of negligence that there is no recognition in negligence of 'relational' loss (ie, 'damage or destruction done to important human relationships': Chamallas and Wriggins (n 179) 89.

180 In a non-pandemic context, however, there are some decisions on the writ of habeas corpus in aged care: Antunovic v Dawson (2010) 30 VR 355; Public Advocate v C, B (2019) 133 SASR 353; Skyllas v Retirement Care Australia (Preston) Pty Ltd [2006] VSC 409. See also discussion in Victorian Law Reform Commission, Guardianship (Final Report No 24, April 2012) ch 15.

181 Michael Legg, 'Tort Wars: Class Actions Set to Increase as Laws Wind Back', The Conversation (online, 4 December 2014) <https://theconversation.com/tort-wars-class-actions-set-to-increase-as-laws-windback-32707>.

182 Pam Stewart and Anita Stuhmcke, Australian Principles of Tort Law (The Federation Press, $4^{\text {th }}$ ed, 2017) $8-10$. 
harmful culture and set of practices towards people in RACFs across the aged care industry. ${ }^{183}$

\section{TOWARDS A POLITICS OF ABOLITION}

We now turn to consider the legal lessons and analytical connections across legal regimes of control and confinement. Both forms of litigation have highlighted the particular vulnerabilities of people in IDCs and RACFs, while emphasising the power of strategic litigation or class actions to make visible ongoing harms and compel possible alternative arrangements to detention and confinement. Nonetheless, our analysis also highlights the risk that civil litigation, based on duty of care principles, may merely reproduce or legitimate the very regimes of confinement that subject people to harm, rather than questioning their foundations. We nonetheless suggest that certain legal remedies oriented towards deinstitutionalisation and decarceration may challenge the particular logics of disposability at work towards elderly citizens and asylum seekers and other criminalised non-citizens within sites of confinement. In particular, we point to some key areas of future consideration in legal scholarship and advocacy during and beyond the pandemic.

Comparing COVID-19 civil litigation concerning IDCs and RACFs illuminates fundamental differences in understandings of confinement as well as the legal, practical and political consequences of these understandings for the ongoing legitimacy and legal accountability of IDCs and RACFs. As noted above, a key distinction between the legal accountability strategies across the two sites of confinement was that the legal actions vis-à-vis immigration detention were

183 Despite the possibilities of negligence class actions as vehicles for aged care industry accountability, the possibility of achieving this might be hindered by strategies available to the aged care industry (aided by lawyers) to avoid accountability. These strategies include those commonly engaged by class action defendants to 'resist claims by invoking technical arguments about the requirements and appropriateness of the class action mechanism': Murphy and Cameron (n 173) 412. Moreover, some corporate law firms in Australia servicing the aged care industry are offering general guidance on how to reduce the chances of class action litigation. For example, McCullough Lawyers states 'COVID-19 class action activity has already commenced with plaintiff law firms circling potential targets' and offers guidance to organisations on 'what [they] can do to protect [themselves] against a COVID-19 class action': Jason Munstermann et al, 'Protecting Against COVID-19 Class Actions', McCullough Robertson (Blog Post, 30 March 2020) < https://www.mccullough.com.au/2020/03/30/protecting-against-covid-19-classactions/>. Many of their suggestions are targeted at keeping matters out of court or formal dispute resolution processes. A disturbing development in the United States is the state-based legislation and executive orders for immunity for civil and sometimes even criminal liability of nursing homes during the pandemic: 'US: Ensure Oversight, Not Immunity, for Nursing Homes', Human Rights Watch (Web Page, 15 June 2020) <https:/www.hrw.org/news/2020/06/15/us-ensure-oversight-not-immunity-nursinghomes>; Ina Jaffe, 'Nursing Homes Ask States For Immunity From Civil Suits Amid COVID-19', NPR (online, 23 April 2020) <https://www.npr.org/sections/coronavirus-liveupdates/2020/04/23/842153768/nursing-homes-ask-states-for-immunity-from-civil-suits-amid-covid19>; Tara Sklar and Nicolas Paul Terry, 'States Are Making It Harder to Sue Nursing Homes over COVID-19: Why Immunity from Lawsuits Is a Problem', The Conversation (online, 9 June 2020) $<$ https://theconversation.com/states-are-making-it-harder-to-sue-nursing-homes-over-covid-19-whyimmunity-from-lawsuits-is-a-problem-139820>. 
proactive and sought to prevent ongoing COVID-19-related harms to specific people incarcerated in IDCs, while the legal actions vis-à-vis RACFs were largely reactive and initiated in the aftermath of numerous people having died in both of the two respondents' facilities. This meant that while the interlocutory orders sought against the Commonwealth in relation to immigration detention were ultimately directed towards preventing an apprehended breach of duty of care and compelling the release of certain people from particular IDCs (even if these have been unsuccessful to date), the legal outcomes being sought in the RACF class actions are largely compensation for past breaches of RACF providers' duty of care.

We argue that this distinction arises for two reasons in particular. First, refugee advocacy has had a longer tradition and clearer focus on the illegitimacy of immigration detention, and a more concentrated advocacy focus on the liberty of migrants. In contrast, there is an ambivalence towards deinstitutionalisation in aged care advocacy, informed in part by current advocacy funding models, ${ }^{184}$ a perceived lack of alternative care options, and a predominant focus in aged care advocacy on improving standards of care within existing RACFs rather than advocating for alternatives. Second, there is greater legislative clarity around the legal basis for immigration detention, as compared to the dominance of choice and necessity as drivers for RACFs, which can mask legal dynamics enabling confinement as we outlined above in Part II. While COVID-19 has given rise to more vocal calls by advocates and scholars for the deinstitutionalisation of the provision of aged care, ${ }^{185}$ our analysis suggests that there needs to be a more legally grounded understanding of certain practices within RACFs as detention, and a strategy of engaging law for deinstitutionalisation. Indeed, such a reconceptualisation of RACFs within aged care advocacy could draw on the strategies, successes, and lessons learned from the immigration detention context while also learning from frameworks developed in a prison context such as 'anticarceral remedies'. ${ }^{186}$ That said, it is important to acknowledge that the recent increased use of torts law in immigration advocacy arose in part due to the limited successes, in the wake of the Lim decision, in challenging the statutory basis and lawfulness of immigration detention. ${ }^{187}$

184 For example, a peak existing advocacy organisation in the aged care sector, Older Persons Advocacy Network ('OPAN'), is predominantly funded by the federal government, which suggests that it may be limited in its capacity to advocate against federal government policies and actions.

185 Matilda Marozzi, 'Aged Care Coronavirus Outbreaks Highlight Need to Stop "Warehousing” People, Council of Ageing Says', ABC News (online, 8 August 2020) $<$ https://www.abc.net.au/news/2020-0808/covid-19-highlights-the-urgent-need-for-aged-care-reform/12534730>; Carmelle Peisah et al, 'Advocacy for the Human Rights of Older People in the COVID Pandemic and Beyond: A Call to Mental Health Professionals' (2020) 32(10) International Psychogeriatrics 1199; Gerard Quinn and Ann Campbell, 'Nursing Homes Must Be Made a Thing of the Past', The Irish Times (online, 20 May 2020) $<$ https://www.irishtimes.com/opinion/nursing-homes-must-be-made-a-thing-of-the-past-1.4257422>; Michael Schulson, 'Coronavirus Is Renewing a Call to Abolish Nursing Homes', Quartz (online, 25 June $2020)<\mathrm{https}: /$ qz.com/1872956/is-there-a-better-alternative-to-nursing-homes/>.

186 Debra Parkes, 'Solitary Confinement, Prisoner Litigation, and the Possibility of a Prison Abolitionist Lawyering Ethic' (2017) 32(2) Canadian Journal of Law and Society 165, 183.

187 Lim v Minister for Immigration, Local Government and Ethnic Affairs (1992) 176 CLR 1. See also Talbot and Newhouse (n 126) 85. Although a comparative analysis is beyond the scope of this paper, it is worth 
Another key difference across the two types of COVID-19 litigation has been the different positioning of legal subjecthood. While the legal actions around IDCs were necessarily initiated on behalf of detained individuals, the plaintiff groups in the RACF legal actions are much more expansive, with a primary focus on the experiences of family members. On the one hand, this possibly highlights the greater status of people in immigration detention as agential subjects, as compared to those in aged care. But it can also be to the disadvantage of each group: people in IDCs are often constructed as being too agential, or failing to comply with government directives to wait in a refugee 'queue' compared to people in RACFs who in contrast tend to be infantilised in protective confinement, subject to others' decisions to move them there. It is thus important to situate legal subjectivity in a broader critique of the construction of political subjectivity. However, our analysis shows how the populations in both sites are effectively treated as potentially disposable or ungrievable lives.

Despite these differences, our analysis illuminates some possibilities of civil litigation to address underlying structural harms and advance a politics of deinstitutionalisation or even abolition. As demonstrated above, negligence as a legal action may be limited in its capacity to adequately redress the structural and collective harms experienced within IDCs and RACFs. Negligence claims necessarily individualise both calculations of risk and determinations of harm. Only particular kinds of risks and harm are recognised in law for the purposes of interlocutory action or eventual damages. This means, for example, that any claimed damages need to be tightly drawn, as individual and as corporeal. ${ }^{188}$ In the COVID-19 immigration litigation, both the applicants had particular comorbidities that increased their individual risk of likely harm or even death if they contracted COVID-19 and their claimed damages included the corporal dimensions of potential 'deterioration of mental harm' arising from the use of solitary confinement as a COVID-19 measure, ${ }^{189}$ while the RACFs COVID-19 litigation similarly stressed the individual experiences of mental harm (including depression, anxiety and nervous shock) of family members when hearing of their family members' deaths. When done in the context of a class action (as in the case of the aged care litigation), negligence can remedy individual harms experienced by a number of people which highlights a wider or mass problem, but cannot redress collective or shared community harm (although the possibility for higher damages bill for defendants might be an incentive for structural change). ${ }^{190}$ As a result, the interlocutory orders in the immigration litigation were also necessarily

noting that the potential for COVID-19 legal actions based on constitutional principles may have more success. In the Canadian context, see Martha Jackman, 'Fault Lines: COVID-19, the Charter, and LongTerm Care' in Colleen M Flood et al (eds), Vulnerable: The Law, Policy and Ethics of COVID-19 (University of Ottawa Press, 2020) 339.

188 Nicky Priaulx, 'Endgame: On Negligence and Reparation for Harm' in Janice Richardson and Erika Rackley (eds), Feminist Perspectives on Tort Law (Routledge, 2012) 36, 38.

189 Plaintiff M37/2020, 'Submissions', Submission in Plaintiff M37/2020 v Commonwealth, VID 272/2020, 24 April 2020, [16].

190 Dayna Nadine Scott, “'Gender-Benders”: Sex and Law in the Constitution of Polluted Bodies' (2009) 17(3) Feminist Legal Studies 241, 251, quoting Joanne Conaghan, 'Gendered Harms and the Law of Tort: Remedying (Sexual) Harassment' (1996) 16(3) Oxford Journal of Legal Studies 407, 408. 
individualised. For example, the court order in Plaintiff M37/2020 stipulated only for the provision of PPE to the applicant, and for the applicant to be given an individual room, rather than covering conditions within IDCs more generally. ${ }^{191}$ This means that the structural harms remain unaddressed, particularly in cases that settle or are discontinued early, such that they may limit public access to the details of the case or inhibit development of the common law or social change more broadly. ${ }^{192}$

While the impacts of COVID-19 for specific plaintiffs in IDCs and RACFs can be deeply personal, corporeal, emotional and familial, on another level, COVID-19 responses can have a 'social as well as an individual dimension'. ${ }^{193}$ Indeed, there is potential for some of the underlying harms of the death, injury and risk in immigration detention and residential aged care failing even to register as a breach of duty of care: after all, the confinement of large numbers of older and disabled people in RACFs and of people held in close proximity in IDCs is part of the very design of such places and what they are funded to do ${ }^{194}$ Negligence might not be capable of addressing such manifestations of 'slow violence'. ${ }^{195}$ Sites of confinement tend to produce forms of injury which are slow and diffused, constituting social 'wounds' which are nonetheless incapable of being 'captured by our current legal imaginary'. ${ }^{196}$ On the other hand, establishing a particular acceptable legal standard of care for the treatment of people within these spaces can also have the indirect effect of legitimating sites of detention and confinement per se, that for instance allows the courts to prescribe particular measures intended to 'reform' or make IDCs 'safer' during exceptional health emergencies, and in doing so act to legitimate the logic of incarceration at state borders. ${ }^{197}$ As a consequence, negligence litigation and the class action mechanisms may

191 Order of Kenny J in Plaintiff M37/2020 v Commonwealth (Federal Court of Australia, VID272/2020, 24 April 2020).

192 There is a rich body of civil procedure scholarship on settlements and social justice. For two of the wellknown contrasting perspectives (albeit in a United States perspective), see Owen M Fiss, 'Against Settlement' (1984) 93(6) Yale Law Journal 1073; Carrie Menkel-Meadows, 'Whose Dispute Is It Anyway? A Philosophical and Democratic Defense of Settlement (In Some Cases)' (1995) 83(7) Georgetown Law Journal 2663. For a more recent consideration in a context of structural harm, see also Leora Bilsky, The Holocaust, Corporations, and the Law: Unfinished Business (University of Michigan Press, 2017). See also some of the disadvantages with settlement specifically in the class action context: Michael Legg, 'Class Action Settlements in Australia: The Need for Greater Scrutiny' (2014) 38(2) Melbourne University Law Review 590.

193 Scott (n 190) 251, quoting Conaghan (n 190) 408.

194 Dayna Nadine Scott has explored this in the context of environmental pollution: Scott (n 190) 245-6. See also Loughnan, "Not the Hilton": "Vernacular Violence" in COVID-19 Quarantine and Detention Hotels' (n 16).

195 Rob Nixon, Slow Violence and the Environmentalism of the Poor (Harvard University Press, 2013). In the immigration detention context, see Rohanna Stoddart, Paul Simpson and Bridget Haire, 'Medical Advocacy in the Face of Australian Immigration Practices: A Study of Medical Professionals Defending the Health Rights of Detained Refugees and Asylum Seekers' (2020) 15(8) PLoS One e0237776.

196 Dayna Nadine Scott has explored this in the context of environmental pollution: Scott (n 190) 252.

197 See generally, Sara Dehm, 'International Law at the Border: Refugee Deaths, the Necropolitical State and Sovereign Accountability' in Shane Chalmers and Sundhya Pahuja (eds), Routledge Handbook of International Law and the Humanities (Routledge, 2021) 341. 
ultimately bolster efforts to 'better' regulate IDCs and RACFs, rather than question the confinement and institutionalisation of people within these sites.

Nonetheless, COVID-19 litigation can prompt critical public and legal conversations around produced vulnerability, social responsibility and legal accountability in these sites. For example, Dayna Nadine Smith, following Sarah Jain, has argued that 'the function of tort law is not only to compensate the injured, but to do the political and social work of deciding what will count as injury and to make physical injuries material'. ${ }^{198}$ This allows us to conceive of COVID-19 litigation as raising fundamental questions about the distribution of political, legal and ethical responsibility in society. ${ }^{199}$ While negligence law does not require those responsible for certain harms to think ethically about social relations or to question structures that ultimately place people in situations that give rise to individual breaches, specific legal remedies and the broader framing of these cases could compel public attention to such questions. For example, family members involved in the St Basil's COVID-19 litigation have stressed that the case is much more directed towards promoting increased transparency around RACFs than it is about individual compensation. In the words of one family member, the case is 'the only way of establishing what went wrong' because, as he stated, '[w]e have bits and pieces of a jigsaw puzzle, but there's still a lot of pieces missing' ${ }^{200}$ In this way, litigation may be able to facilitate 'cracking open a window and shedding light on the utter inhumanity' of practices of confinement, and, in doing so, expose the harms of systemic institutionalisation in sites like RACFs and IDCs. ${ }^{201}$ This is particularly important given the closed nature of these institutional settings, their limited visibility and the lack of information provided to family members or the public at large during COVID-19. ${ }^{202}$

Moreover, when embedded in social movements that call for decarceration, strategic litigation can be a useful point of intervention to advance a politics of abolition. Debra Parkes has importantly suggested that strategic litigation in a prisoner rights context in the United States can challenge the carceral logics of systemic mass imprisonment provided that it is embedded in a prison abolitionist ethics and social movements, rather than focused on efforts to better regulate or reform prisons. For Parkes, this means developing legal arguments 'in a way that rejects carceral logics, rather than legitimizes them' and seeking non-carceral remedies. Otherwise, Parkes argues that

198 Scott (n 190) 247, citing Sarah S Lochlann Jain, Injury: The Politics of Product Design and Safety Law in the United States (Princeton University Press, 2006). See, however, the criticisms of the 'loss spreading' impact of insurance: Joanne Conaghan and Wade Mansell, The Wrongs of Tort (Pluto Press, $2^{\text {nd }}$ ed, 1999) 12. In the context of class actions, see Murphy and Cameron (n 173) 404.

200 Houston et al (n 162); Sarah Curnow and Pat McGrath, 'Senior Doctor Says Aged Care Still Faces Surge Workforce Shortage, as Class Action Launched against Epping Gardens', ABC News (online, 19 August $2020)<$ https://www.abc.net.au/news/2020-08-19/coronavirus-doctor-says-aged-care-surge-workforceshortage/12569444>.

201 Parkes (n 186) 178.

202 For instance, the Department of Home Affairs has not released any figures on COVID-19 testing or PPE measures in IDCs to date. 
if, for example, we seek only to abolish those smaller cages (solitary confinement) but leave intact the logic of caging people in the first place, then some other correctional tool or practice will take the place of solitary and we will soon be fighting that. ${ }^{203}$

Seen in this light, the COVID-19 litigation may not only provide an important means of facilitating transparency and access to specific information across both sites, but might also advance anti-institutionalisation sentiments or decarceration measures, and thereby a broader abolitionist politics. This will particularly be the case if the court remedies sought and ordered prompt a collective institutional response rather than simply adopt individualised remedies like compelling the provision of more PPE to specific people within specific sites of confinement, or directing certain detainees or residents to be accommodated in individual rooms or subject to self-isolation measures.

\section{CONCLUSION}

We conclude by urging more careful reflection in two respects on the legal, political and social responses to IDCs and RACFs beyond the pandemic. First, we caution against being so absorbed with the virus that the real crisis recedes from view. We argue that it has been the response to the pandemic which has been the source of most harm for particular groups in society. ${ }^{204}$ Notwithstanding that preexisting medical conditions might predispose people to greater harm from COVID-19 exposure, it is clear that where there are adequate protective measures, and where people are able to socially isolate and move in open, well-ventilated spaces while maintaining access to social supports, they are less likely to become infected and more likely to be able to access appropriate medical care should this occur. The emergence of COVID-19 class actions and strategic litigation in the context of RACFs and IDCs illustrate this point, with the turn to law seeking to redress not harms from the virus per se, but those emerging from institutional failures to deliver adequate care during the pandemic. Announcements by the federal government for additional funding to address the 'trauma' experienced in aged care due to the crisis, ${ }^{205}$ and the re-opening Christmas Island to purportedly

203 Parkes (n 186) 179. See also on anti-carceral remedies: Sheila Wildeman, 'Disabling Solitary: An AntiCarceral Critique of Canada's Solitary Confinement Litigation' in Claire Spivakovsky, Linda Steele and Penelope Weller (eds), The Legacies of Institutionalisation: Disability, Law and Policy in the 'Deinstitutionalised' Community (Hart, 2020) 87.

204 A similar argument is made in Flood et al (n 107) 10, where the editors reflect that 'COVID-19 has exposed and created vulnerabilities that follow the fault lines of pre-existing structural inequities. COVID-19 has flourished in settings where people were already vulnerable because of government policies and corporate bottom lines. Many of the virus's hot spots in high-income countries (HICs) long-term care homes, prisons, immigration detention centres, and slaughterhouses, among others - are spaces of acute vulnerability because they are sites of long-standing structural inequalities. Governments have long tolerated substandard quality of care in long-term care homes, caused by, among other things, understaffing and low wages'.

205 Joseph Ibrahim, 'The Government Has Thrown Another \$171 Million at the Problem; But a Real Plan for Aged Care Has Been Missing All Along', The Conversation (online, 25 August 2020)

$<$ https://theconversation.com/the-government-has-thrown-another-171-million-at-the-problem-but-a-real- 
deliver greater 'safety' than in onshore IDCs, point to this ongoing failure in the Australian government's response, not the risk of the virus. ${ }^{206}$ Accordingly, we argue that COVID-19 is a prism that brings into sharper relief existing inequalities including the injustices and inequalities of regimes, sites and practices of confinement generally. We thus support calls to 'never waste a crisis' and ensure 'the structures of inequality are seriously challenged', ${ }^{207}$ to see COVID-19 as a 'portal, a gateway between one world and the next', ${ }^{208}$ and to press for an appreciation and transformation of those structures which lead to some groups being more exposed to harms (sickness and death) than others.

Secondly, this is an opportunity, in the words of Anamika Misra, to be sufficiently '[d]aring to give humanity a different future beyond the pandemic of coronavirus and racism [requiring] a radical re-imagining of humanness and the ethics of being-human-in-the-world ${ }^{\prime 209}$ Such considerations mean that there is an urgent need for more critical engagement with how vulnerability is produced as an effect of systems of confinement themselves, rather than merely by COVID-19. ${ }^{210}$ Our concern is that COVID-19 is 'overshadowing' underlying factors which lead to greater risk regardless of the pandemic. Positioning the virus as the threat eclipses the violence of those legal regimes which, when coupled with COVID-19 measures, enhance COVID-19 risks and harms for particular groups.

In conclusion, our analysis has highlighted how some people, already regarded as more disposable than others, have been subjected to a heightened logic of disposability as an effect of COVID-19 measures, in which the economic value and cost of preserving life appears to be the overarching metrics. ${ }^{211}$ Nonetheless, legal responses challenging such calculations are also gathering momentum to offer a limited form of legal accountability. Our analysis of these litigations points to broader challenges and opportunities facing lawyers and legal scholars

plan-for-aged-care-has-been-missing-all-along-144929>; Scott Morrison, 'Reinforcement of Australia's Aged Care Sector' (Media Release, 21 August 2020) <https://www.pm.gov.au/media/reinforcementaustralias-aged-care-sector>.

206 As outlined above in Part III, the trauma in aged care was produced by a failure to act, and the vulnerability of those in onshore detention is an effect of the way those centres are operated. See also Patricia J Williams, 'The Endless Looping of Public Health and Scientific Racism' in Burris et al (eds) (n 3) 257.

207 Sundhya Pahuja and Jeremy Baskin, 'Never Waste a Crisis: A Practical Guide?', Critical Legal Thinking (Blog Post, 20 March 2020) <https://criticallegalthinking.com/2020/03/20/never-waste-a-crisis-apractical-guide/>.

208 Arundhati Roy, 'The Pandemic Is a Portal', Financial Times (online, 4 April 2020) $<$ https://www.ft.com/content/10d8f5e8-74eb-11ea-95fe-fcd274e920ca $>$.

209 Anamika Misra, 'Humanity's Catastrophe: Following Sylvia Wynter in the Age of Coronavirus', Critical Legal Thinking (Blog Post, 10 April 2020) <https://criticallegalthinking.com/2020/04/10/de-prioritisinghumanity/>.

210 As Tess Sheldon and Ravi Malhotra note in relation to people with disability in Canada, the pandemic is both a 'a disaster and an opportunity', providing us with 'the perfect time to reimagine our relationships to society and to each other': Tess Sheldon and Ravi Malhotra, 'Not All in This Together: Disability Rights and COVID-19' in Colleen M Flood et al (eds), Vulnerable: The Law, Policy and Ethics of COVID-19 (University of Ottawa Press, 2020) 419, 431.

211 Patrick Wintour, ‘Tony Abbott: Some Elderly Covid Patients Could Be Left to Die Naturally’, The Guardian (online, 2 September 2020) < https://www.theguardian.com/australia-news/2020/sep/01/tonyabbott-some-elderly-covid-patients-could-be-left-to-die-naturally>. 
emerging from COVID-19 in terms of how harms of confinement are articulated and contested, and how law can be further engaged to shift from a focus on care (or even survival) within these places to a focus on flourishing beyond them. Considering such civil litigation concerning IDCs and RACFs in relation to a politics of abolition and deincarceration then is an invitation to explore what a society based on political inclusion and the building of more just communities might look like. 